\title{
\#DecolonialEnlightenment and Education
}

\author{
Johannes A. Smit
}

Thought is freedom in relation to what one does ...

(Foucault [1984] 1991: 388)

\section{Abstract}

This article provides a few brief, historicisable perspectives on what we may call the Truth, or Knowledge, of the Decolonial in the history of thought in South Africa. It explores what we may mean when we talk of the Colonial and the Decolonial, their Truth(s) and Knowledge(s), as well as how we could contribute to the continuous developing of the Decolonial through research, and research-led teaching and learning. Referencing Scott's notion of 'hidden transcript', I provide a few pointers as to how to engage such references to the beginnings, and roots of the Decolonial in our context. I also provide a few conceptual perspectives on how to view history in Africa, from the vantage point of this approach, how to focus our research especially on thought-asresistance, and the imperative to engage the digitally globalizing world. Finally, I provide a few perspectives on my notion of \#decolonialenlightenment, and the significance of the quotation at the beginning of this article. Originally a paper that was invited to the plenary on 'Conceptualising Decolonisation and Africanisation' at the Zululand Humanities and Social Sciences Conference, 18 - 20 October 2017, the article intends to open up (further), and contribute to the continuous developing intellectual space for decolonial thought and knowledge production in the Arts and Humanities. These must be positioned within the broader framework of the educational transformation processes South Africa has engaged and gone through, since the first education White Papers and related educational decisions and directives were released and implemented since 1995/ 1996. I shall therefore front my argument with a brief overview focused on this matter. 
Keywords: Higher Education in South Africa, transformation processes, the Decolonial, the Colonial, world-historical paradigm, knowledge-power, Council of Policy, enlightenment, \#DecolonialEnlightenment

\section{Introduction}

This article provides a few brief, historicisable perspectives on what we may call the Truth, or Knowledge, of the Decolonial in the history of thought in South Africa. It intends to open up (further), and contribute to the continuous developing intellectual space for decolonial thought and knowledge production in the Arts and Humanities. In terms of the outside of thought of the Colonial that developed through various phases of the diverse forms of colonization perpetrated on the South, the argument is primarily two-fold ${ }^{1}$.

Firstly, and this has been done to various degrees by a variety of scholars from North and South, working in the anti-, resistance, and later post/colonial paradigms, the Colonial, as a knowledge-power bloc has to be traced and deconstructed. Amongst others, the main strategies have been to objectify and historicise colonizing knowledge-power in its artificiality and inhuman and a-moral vicious physical, psycho-traumatic, and materio-culural effects on the colonized other ${ }^{2}$. In this regard, it is important, to view the knowledge-power complex that accompanied and asserted itself in close and in an integrated manner with colonisation, as, what we may call, a knowledgepower $b l o c^{3}$. Relatedly, in Europe, as in America, there have been numerous

${ }^{1}$ This article is based on a paper delivered at the $8^{\text {th }}$ Zululand Humanities and Social Sciences Conference, 18 - 20 October 2017, Richards Bay. It was a contribution to the conference theme, 'Conceptualising Decolonisation and Africanisation', and introduces new conceptualisations for the purpose of decolonial knowledge production, and decolonial research-led teaching and learning, or, decolonial education for short.

${ }^{2}$ Discursively, some studies, from both North and South, using, and developing especially Michel's Foucault's methodological specific genealogical tracing of the construction and development of colonizing discourse in the Arts and Humanities, have started to appear since 2000.

${ }^{3}$ I draw this notion from Foucault (1994:338), where he speaks of a knowledge that accumulates and forms a power bloc, in which 'power relations constitute 
competing discursive formations, depending on the level of abstraction, representing specific historicisable knowledge genealogical networks in the production of intellectual commodities, outside the dominant and hegemonic discourse or paradigm, competing with it for position and hegemony. As such, these competing discourses are in effect on the outside of the hegemonic or dominant colonizing thought and its products, that held sway at specific times and in specific circumstances. In critical scholarly endeavours, scholars have tried to delineate the complexity and diversity but also the European and American 'provincialisms', in their dispersal, of these competing discourses. So, even though one can group the colonizing knowledge-power bloc of especially the nineteenth and twentieth centuries as an integrated interdisciplinary 'Western', 'Euro-American', or more specifically, an 'AngloAmerican' bloc, its often siloed complexity, inherent diversity but also competing 'provincialisms' have to be exposed ${ }^{4}$. These two perspectives on the Colonial are briefly further explicated in the second part of this article below.

Secondly, and this is the main point of this article, we need to start to let the light of reason in the academy fall productively on the historically marginalized, hidden, off-stage discourse(s) of resistance and critique in the history of colonial encounter ${ }^{5}$. These are mostly only intimated in our sources and archives, or present as brief traces and remnants of thought and action or remainders of socio-historical memory outside of the broader, hegemonic colonizing knowledge-power blocs-in-formation, and mostly not accommo-

regulated and concerted systems'. Inherent in his description, is what he elsewhere calls a knowledge-power bloc.

${ }^{4}$ As such, we can speak of 'the' or 'a' 'Decolonial' knowledge, or knowledgepower system. This is done in the context of the fact that we still use the concept 'colonial' in the notion of the 'decolonial', and not something else. My argument, here, is that, despite diversity, and heterogeneity, inherent in both concepts, and the related knowledge systems they designate, we do in fact assume homogeneous 'blocs' of knowledge in our use of the concepts of both 'Colonial' or 'the' or 'a' 'Decolonial', and that we should get clarity about this.

${ }^{5}$ I know that many scholars have already contributed to this project, but I shall in this article provide a few pointers to an actual knowledge production strategy that could be followed in this endeavor to further, deepen, and advance it. 
dated in curricula ${ }^{6}$. It is these traces, remnants and remainders, or 'hidden transcripts ${ }^{77}$ that need to be tracked and built out in their full socio-historical and socio-cultural complexity, block-by-block, to add on to and constitute a decolonized knowledge-power complex or bloc - obviously also accommodating its own complexity and diversity ${ }^{8}$, in the South, so to speak. I provide the pointers ${ }^{9}$ by looking at what could be called the historical 'beginnings' and 'roots' of the Decolonial, with a specific brief focus on the

${ }^{6}$ As an aside, I can also mention, that I have found that these traces are also present in the self-doubt, interventions or postponements of intervention and especially the discursive knowledge-power censure as well as pre-emptive self-censure by colonizing agents, in the face of a certain powerlessness or apprehension or misgivings of the Colonial.

${ }^{7}$ I use Scott's (1990) helpful notion here. He has contrasted it with his notion of 'public transcripts', and explicated, developed and used it in a number of ways - cf. especially his 'Introduction'. In my own approach, I think there are possibilities to develop it further as part of research into anti-colonial and resistance discourse, as indicated in this article. I also think that an approach such as Scott's adds to those such as Bhabha's (1994) of 'sly civility', 'mimicry', etc. In my view, we need to also go beyond the identification of the ambivalent and de-constructed, to the production of useful discourse in the developing world, where this is not happening as yet. Cf. also Scott (2013.)

${ }^{8}$ As such, we can use the notion of 'the Decolonial', and argue that this should be positioned within a new or different paradigm, both historically or diachronically, and synchronically, than the colonizing one we have been subjected to up to now. The latter, I argue, and as virtually all intellectuals who participated in the broad-based 'postcolonial' paradigm that developed since the late 1950s and early 1960s argued (starting with Es'kia Mphahlele and Franz Fanon, amongst others), should finally be ditched in disciplinary and discursive practice, where this has not happened yet. It is very often still silently assumed and redundant perspectives and prejudices should be unthreaded out of our research, syllabi, and courses (cf. Smit and Van Wyk 1998/ 1999).

${ }^{9}$ It is the knowledge-power that has been and still has to be produced with regard to these pointers or insights, that, pragmatically, positively, effects, motivates and inspires free and constructive thought, creativity, and, not least of all, entrepreneurship. 
significance of what we could call the last stand of the Khoisan in $1799-1803$. This is followed by three brief decolonial considerations, and a last section, where I reflect on the notion of the Decolonial as characterized by 'englightenment' - that initial thought or realization that sparks critique of forces such as those perpetrated by a variety of forms of regulation and colonization, and resistance ${ }^{10}$. As a certain compound of thoughtful and critical intellectualization of resistance, we may call it, \#decolonialenlightenment on the colonial or colonizing border(s), or at the limits, or thresholds, of the Colonial. But, in order to contextualize the argument, let me first reflect on some assumptions that derive from perspectives on the tertiary educational transformation initiatives, decisions and directives, that were implemented topdown, so to speak, dating from the first White papers of 1995/ 1996. This is the academic, and more specifically the question of curriculum content that we need to research and produce, when we debate the issues raised in this article.

\section{The Broader Framework: Higher Educational Transformation Processes since 1995/ 1996}

In my own, honest opinion, the greatest force for change in South Africa since 1994, that groundbreakingly integrated education in South Africa, beyond the apartheid regime's racist education systems, and that cuts across the societal

${ }^{10}$ I regard such thought or realization as the most basic of human thought, in the face of any experience-event of finitude, whichever form it may take. How it is interpreted or brought to understanding, also signifies the most basic - one can even say, primal - human form of reflection on experience, even before it is subjected to the concepts, structures, or categories of understanding. At base, it is the primal-intuitive human response to suffering. Concomitantly, I regard my few pointers as at least some of the most exemplary decolonial events, as events in thought, in the early historical colonial encounters in South Africa, especially on its borders, or colonial and colonizing border-zones. (I obviously do not deal with the very large range of cross- and interdisciplinary scholarly literature that was produced in the wake of the achieving of independence of India (1947) and the many African states since 1957.) 
sectors in South African life, has been school education ${ }^{11}$. It cuts across the political or the state-ideology-power complex, the economic or market-capitallabour complex, and the social-class, or civil society-class-caste complex, as it interacts and intersects with the prior two (adapted from Wallerstein 1996). Not only did the South African Department of Education (1994 - 2008, with the South African Schools Act of 1996) change the structural or generative 'grammar' of the education system in South Africa. With a number of inclusive and non-racial, non-sexist, and non-sectarian Education white papers since 1995, it effectively replaced apartheid's Bantu Education Act (No. 47 of 1953; cf. Moore 2015) and its derivatives - which in fact maintained racial separation at school level even into the transitory 1991 - 1993 period (with the introduction of Models A, B, C, and D schools during this time; cf. Roodt 2011). It also established institutions like the Council on Higher Education $\left(\mathrm{CHE}^{12}\right)$ and the closely related Higher Education Qualification Framework (HEQF) and Higher Education Qualification Sub-Framework (HEQSF, as revised in 2013), responsible for both benchmarking and standardizing all educational courses and syllabi in South Africa.

Together with the South African Qualifications Authority (SAQA) that requires all educational institutions to be registered according to benchmarked levels of education across the country's educational institutions and state sectors' educational requirements, these developments over the last twenty-one years played a crucial role in the transformation of the educational landscape in South Africa. For a greater focus in more efficient administration and management, we also have the splitting of the former Department of Education (1994 - 2008) into the Department of Basic Education (DoBE), and the Department of Higher Education and Training (DoHET), each with its own minister, and full complement of departmental staff, since 2008/ 2009. For universities, and in addition to the horizons opened up for curricula, research

${ }^{11}$ The verdict is still out as to failures of the so-called Outcomes-based Education system that was introduced in 1998, called 'Curriculum 2005'. Cf. especially Jansen's (1997/ 1999) criticisms and two additional perspectives, dating from 2010 and 2018 respectively - those by Jansen and Rice. (I want to thank Rubby Dhunpath for these references.)

${ }^{12}$ The CHE was established in 1998, and started to function as the Quality Council for Higher Education since 2008, as laid down in the National Qualifications Framework or NQF Act of 2008, Act No 67 of 2008). 
and disciplinary transformation by the late 1990s' respective Acts and white papers, the new ministerial departments' qualifications frameworks (since 2008) also provided further conditions for the transforming of the colonial- and apartheid-inherited education systems as well as their curriculum content, together with its continued knowledge-power effects, to transformed curricula, programmes and courses, with greater relevance, characterized by equality, freedom and justice for all.

Against this brief background, and focusing on the research, and teaching and learning level dynamics at ground level in the Higher Education sector, much has happened. Universities restructured themselves in various ways. In 1996/ 1997, universities were required to transform to new postdepartmentally-and-single-disciplinary-configured ivory tower silos, into more inclusive ones, both institutionally, and with regard to switching from discipline-based curricula, into programme-based majors and modules, including both core and elective modules ${ }^{13}$. These had to be submitted to SAQA at the time, and as from 2000, the new offerings were introduced into universities. These dynamics played out alongside the Outcomes-BasedEducation (OBE) system introduced at school level, but which, in time, fell into disrepute, and was silently shelved during the early $2000 \mathrm{~s}$.

The universities entered into another wave of institutional transformation, now externally, by merging with select fellow Higher Education institutions in the same geographical region. The main purpose was to create new institutions characterised by a radically inclusive and equitable university system beyond the racially-denominated universities dating from the apartheid government's Extension of University Education Act (the Act 45 of 1959, rejected and opposed by all South Africans that resisted the hegemonic

${ }^{13}$ The idea was to open up the departments and their majors to one another, especially where they study the same socio-cultural phenomena, but from different knowledge-power perspectives. The argument was - and is, and which I strongly support and advocate - that integrated programmes that equip students with knowledge, skills and conceptual and paradigm resources that have been developed in the different branches of the history of Arts and Humanities, is empowering for what I have called decolonialenlightenment in this article. This allows students to exit with a more trans-disciplinary, integrated qualification, and importantly enable them to transformatively, and creatively, engage problematic and challenging socio-cultural phenomena. 
apartheid state-ideology-power complex $)^{14}$. The latter made it a criminal offence if, and when a Black student would register at a white, or formerly 'open' university. This was rightly a transformational top-down approach, which took place according to legislation in this regard, and DoE directives under the leadership of then Minister of Education, Prof Kader Asmal, in November 2002, with the inauguration of the new merged universities in 2004. Internally, the two-year period leading up to this event, was also characterized by fervent cross-university negotiations between formerly rival faculties, schools, and departments - both inside and outside these institutions - to form new administrative and interdisciplinary educational units within universities institutionally speaking, as well as with regard to the actual curricula content of programmes offered internally in each unit. These were all done according to newly-configured programme and module templates. Here, at the coalface of education, virtually all academics in South Africa have had to re-think their disciplines, programmes, their curricula and their learning outcomes, teaching and learning processes, and, most often and most boldly, ventured into interdisciplinary domains ${ }^{15}$. These dynamics called for academic and intellectual leadership and innovation across the disciplines and programmes.

In the case of the University of KwaZulu-Natal, this was required again, amongst others, as the university reconfigured itself into five Colleges, and nineteen schools, and did away with the Faculty level across the university in 2011, in order, as it was stated at the time, to bring management and academia closer together. It would also mean saving money on a whole layer of management and staffing, and other related faculty-level expenses, but in affect also transferring greater bureaucratic tasks and responsibilities on already pressured and burdened academics. In this exercise, it was primarily

${ }^{14}$ It is from this time that we have the distinction between Historically White Institutions (HWIs) and Historically Black Institutions (HBIs).

${ }^{15}$ There is however evidence that contradict this statement, viz. that some units, especially at HWIs outsourced the developing of these templates with regard to the DoHE directives, and that some academics themselves, did not engage this process themselves. In my view the developing of these templates by these units were instrumental in the extreme, and not engaging the issue of developing curricula that integrate critical perspectives on specific sociocultural phenomena from different relevant disciplinary formations. 
the formation of the new colleges and schools that was focused on, with not much attention paid to the reconfiguration of programmes and modules ${ }^{16}$.

More recently, and indicative of these trends of transformations and changes in Higher Education in South Africa, and on focusing on bringing about ever greater interdisciplinary research, programme- and moduleofferings, with the idea to improve the quality and content of the qualifications with which students graduate and exit university, the University of KwaZuluNatal launched its new University of KwaZulu Natal Strategic Plan 2017 2021 (2017). As before, and here too, the university has also put inter- and trans-disciplinary research and teaching and learning programmes and projects high on its agenda for the next five years. Amongst others, it also envisions that a select number of cross-college trans-disciplinary areas will be identified as part of the university's 'investment' in 'cutting edge' 'research flagships' that will attract and retain the best students and staff (p. 9). These will lead, promote, and advance such inter- and trans-disciplinary collaboration across the university, not least, in the number one identified research flagship of the university, focused on 'inequality', viz. 'Social Cohesion - Addressing Inequality and Promoting Nation Building' (p. 10). Given the extremely large wealth-gap in South Africa, this focus is to be commended. It is also heartening to notice that the DVC, Dr. Albert van Jaarsveld in his 'Foreword' to the Strategic Plan (2017:1) linked 'transformation' to 'excellence' in everything the university does, especially in terms of its main functions of knowledge production and engagement of stakeholders and communities. These two practices - transformation and excellence - should be 'pervasive' and 'deeply entrenched' in everything the university does. He says,

This strategy demonstrates our commitment to achieving transformation and excellence through our core function as a knowledge agent, as well as through our engagement with stakeholders and communities. Transformation and excellence are both pervasive elements that are deeply entrenched throughout the strategy to shape the future of the University (e.a.).

${ }^{16}$ I regard this as a lost opportunity inside the university system, as to the further developing of the idea of programme development that may better equip students in their Arts and Humanities studies, for public life and culture (cf. note 13 above). 
From the perspective of this brief overview of the framework for my argument, and as much as we could observe from within the social transformational dynamics of the universities, i.e. from our own participation in the educational transformation of the South African educational landscape, from the coalface, and bottom-up, so to speak, much has changed, then, compared to the pre-1994 educational dispensation. Yet, despite these initiatives, and despite the various phases of the ostensibly radical transformation of the Higher Education landscape in South Africa over the last twenty-one years, and rethinking and reconstructing disciplines and programmes from the ground up so to speak, there remains widespread discontent amongst students. It appears as if, not enough has been done. Amongst others, this has become most apparent in the cross-university and cross-campus \#RhodesMustFall (\#RMF), \#FeesMustFall (\#FMF), \#DecoloniseMyCurriculum, and \#WhyIsMyCurriculumSoWhite student movement action mobilisations, if not 'uprising' or 'revolts', as in the view of Booysen et al. (2016). In this article, I shall not scrutinize the discourse of these hashtags in terms of their dynamics, possible undercurrents, their linking with a general dissatisfaction with government and governance in South Africa as has become evident in the numerous 'service delivery protests', their articulations with 'labour' (or not), nor the very real substance of the actual dissatisfaction with the exorbitant university fees primarily parents of students coming from poor households have to pay per annum for their studies, nor accusations of a so-called 'third force' at work at universities. My focus is different, in so far as I shall attempt to answer the more prominent and central question as to why we have the student demand for \#decolonialeducation, so central to much of this discourse, and how we can engage it constructively.

On the one hand, and focusing on its material aspects, we can link this discontent to the actual and physical vandalizing of the Cecil John Rhodes, and other colonial and apartheid-era statues, and other works of art, dating from the colonial and apartheid periods. Why did the students of the \#RhodesMustFall movement, focus and aim their discontent, physically, and materially, at the statue of Cecil John Rhodes? Why was the discontent aimed at this statue, and particularly this one, so vehemently? For many, the answer is simple: Rhodes was a racist, colonial figure that represents historico-colonial ideological oppression and the economic exploitation of labour. As such, his statue is a collective symbol of such oppression and exploitation. And, given its very strategic and prominent place at the University of Cape Town - just one of his 
links to education in South Africa - in front of the panorama of the University's most prominent buildings, it was the closest physical but also symbolic object against which the student movement could vent its discontent and frustration. The student action in the interests of 'decolonised' education itself, can therefore said to be symbolic. But, secondly, this is precisely my point: if this was symbolic action in the interests of decolonized education, what precisely is the content of such decolonized education ${ }^{17}$ Central to my question too, and this despite all the transformations that the Higher Education sector has gone through - with certain academics participating and others not - over the last twenty-one-odd years, is the awareness of all-and-sundry, that for some reason or another, this has not gone far enough. What the students have been saying, is that they do not experience 'decolonized' education. And, I think, this must be taken seriously by the academic fraternity, right through from the knowledge-power holders of the SAQA-CHE complex to the various academics employed in the different research and education paradigms by tertiary institutions in South Africa. As said, I provide some pointers to address this matter in this article, not discounting what has been done and accomplished already.

\section{'The Colonial' and 'The Decolonial'}

By using the notion of what I call the Decolonial, meaning the Truth(s) of decolonisation, or you may also say the Knowledge(s) of decolonization, we need to first ask the question about the Colonial, the Truth(s) of colonization, or the Knowledge(s) of colonization, in a comprehensive and inclusive sense, the Colonial. For many, this would seem superfluous, or even self-evident, given the large array of books and journals, dissertations and theses, encyclopaedias, and dictionaries, government reports, and council and commission reports, produced by colonial and post-colonial institutions, publishing houses, and tertiary institutions, and that range from unidisciplinary to multi- and trans-disciplinary approaches to knowledge production. These all represent a range of knowledge paradigms, that, in various ways represent such Truth(s) or Knowledge(s) of the Colonial. I think we need to have some understanding of the Truth, this Knowledge, especially

${ }^{17}$ I regard Nyamnjoh's (2016) argument addressing this issue from a migrancy perspective as an important aspect of the debate, but not the principal one. My few pointers below, I believe, address the main challenge head-on. 
in the Human Sciences, so that it can help us in determining what we mean by its o/Other - the Decolonial Truth or Decolonial Knowledge, the Decolonial. Historically speaking, we may also ask as to the roots, of this paradigm, the Decolonial. We can ask the questions, and do the research as to the Truth(s) or Knowledge(s) of the Decolonial in the history of decolonial thought. As said, in relation to the Colonial, this is its outside. And, I shall deal with this in the next section. For this present theme, though, there are two perspectives, on this relation, or rather, networks or patterns of force of this outside with regard to the Colonial.

Firstly, within the ambit of the Colonial, and in terms of its own internal relations of force, it has its own competitive outside. This outside, as well as how it competed with the inside of the Colonial, were primarily constituted by the competitive nature of different power-holders or interest groups, or factions or divisions of force and power outside the controlling colonial power, whether in the form of a company functioning for its own benefit, or for the benefit of a government, or in the form of an actual government, functioning for itself, or their many detractors, such as the eighteenth century deists, ideologues, and abolitionists. With regard to colonial or colonizing entities, both those in power (so to speak), and those outside power, collectively, and in a wide variety of ways, collectively participated in the production of truth(s) and knowledge(s) that we could collectively call the Colonial. There was not one single, collective paradigm, unity of knowledge, or system of power in itself, though. In Europe, it was extremely diverse, with knowledge being produced with local relevance, in all the emerging European, and, since the late 1700s, the American 'nations' of the time, but all knowledge, to some extent, aiming to participate in and also compete in the production of a knowledge or knowledges that are transnational, or even transversal. The idealized unity of this knowledge was inspired, at its centre, by the turn to the 'natural', believing that there would be natural laws to be discovered. And, this is why we have such important disciplines as Natural Theology, Natural Philosophy, and Natural Science arising during the eighteenth and nineteenth centuries, and impacting the colonies - mostly showing how the indigenous populations in various ways relate to 'the natural'. All those eighteenth century colonial and imperial power-holders that formed part of the aristocracy, and the cohorts of bourgeois intellectuals, of the different factions, or those against them, or even those with revolutionary objectives (in the eighteenth century, or mid-nineteenth centuries) or even anarchic ideals and tendencies (from the 
mid-nineteenth century onwards, e.g. Proudhon $)^{18}$, collectively participated in the production of this knowledge. This is all on the surface so to speak. In its dispersal, power-holders sought to draw on and enlist those producing such knowledge, in their own competition for influence, power, capital accumulation, forming certain companies, associations, organisations, and 'societies'. To various degrees all were critical of one another, competing with one another, and aimed at the amassing of as much knowledge and power and influence of the general European populace, the masses. The production of their own 'knowledge-power' systems, were central to these competitions. Politically speaking, the faction that won out, at the end of the day, is the faction that makes the rules, makes the laws, and administers and regularizes them.

With regard to the outside of the Colonial, then, there was a thinking outside, or, in competition with the Thought or Knowledge of the existing Colonial dominant, in so far as it competed to make the rules, to make the laws, and administer and regularize them, and to be the beneficiaries of the proceeds and profits of the Colonial. There is no 'invisible hand' of knowledge-power à la Adam Smith ([1776] 1985), here. Everything is visible and on the surface, even in critique. It is observed in the numerous formations (and de-formations) and meetings of clubs and societies, publications, the extensive developing of bureaucracies, all engaged in the same objective - to produce knowledge, linked to power. In the colonies, the effects are seen - how this knowledgepower is practiced - in the mapping of the land, the bureaucratic allotment of land, despite the presence of its inhabitants, and the accompanying physical violence perpetrated on the bodies of its others, in the brutal and cruel realities of enchained slavery, wanton murder, ethnocide, genocide, holocausts, and the rampant rape of women (and children and men? ${ }^{19}$. In terms of the broad-based geo-political system, the two revolutions in America and France respectively, did not change this reality. It did not affect the geo-colonial much. Whether it was perpetrated by Spain, the Netherlands, Britain, France, Belgium, or Italy,

${ }^{18}$ Tharoor (2010) provides a very concise overview, indicating the importance of anarchic organisation in the late nineteenth and early twentieth centuries important, and often ignored, in the history of European Thought. The research question, here, could be, the articulation of the 'Anarchic' with the Decolonial. ${ }^{19}$ This part of the colonizing history of South Africa has not been written, but see Barrow (I 1801:85) amongst others. 
the effects, its pragmatics, remained the same ${ }^{20}$. The colonial or colonising world-system as a system of knowledge-power or power-knowledge, were in its variable and diverse processes of formation, administration and effect(s), the same. The outside of Thought in this instance, is not that of the Decolonial, but that of the Colonial, in terms of the object of colonialisation, to do this even better, and more efficiently than the existing, or previous or competing Colonial at a particular point in time and in a specific geographical space. It is due to this competition, between the Colonial and its own outside (or outsides), that we see a continuous rising in intensity and the concentration of force and power gathering momentum and increasing its effects, streamlining its pragmatics, in the late nineteenth century and throughout the early twentieth century. There is an escalation and heightening of forces, strategies and tactics, a gathering of momentum, and an increase in violence, especially structural, moving from the more overt and blatant brutality of the earlier deterritorialisation campaigns and obliteration of indigenous populations, to

${ }^{20}$ For the diversity of conflicting and competing knowledge formations/ systems in Europe as part of the intra-European colonising processes, cf. de Sousa Santos (2014:17ff). The internally colonized countries, such as Portugal and Spain - who, in history, have themselves been internal and external colonisers - became 'sub-ordinated in economic, political, and cultural terms to north ern Europe and the core that produced the Enlightenment' (de Sousa Santos 2014 ) in the $18^{\text {th }}$ and $19^{\text {th }}$ centuries. Significant for our purposes, is to note too, that de Sousa Santos says that those internally colonised were described as 'lazy, lascivious, ignorant, superstitious, and unclean'. This kind of rhetoric is pathologically part and parcel of colonising discourse, because it simultaneously legitimates the superiority of the coloniser, as well as the excesses of colonising practices - such as rampant murder and rape. (For this, I do not have to remind the reader of all the intra-European paintings, literature, and other aesthetic artefacts that European artists have produced about these realities since the 1500s.) The legitimising rhetoric also served to spell out, suggest or 'nudge' (in current parlance) and conscientise colonising forces to adhere to the 'values' (of superiority) of the colonising ideology and its mission. For a more expanded argument about the European 'diversity' here referred to, cf. Carey and Festa (2009) - especially for their notions of 'enlightenment without others' and the multiplicity of 'postcolonial enlightenments'. As explained in this article, such multiplicity is inherent in both the Colonial and the Decolonial. 
the more subtle and indirect control and rule of decimated indigenous populations hoarded into reserves, throughout the $19^{\text {th }}$ century, in the colonies $^{21}$.

Secondly, however, there is also an outside of thought, outside the competitive outside of the Thought, Knowledge and relations of forces of the Colonial. This is the outside of thought, that asserts life, that asserts human life contingently - as well as in memory - and in the face of the murderous and multiplying horrors of the Colonial. Here, at the limit experiences of existence, life itself, is the political object - articulated in the authenticity and candor of speaking truth to power in the midst of the colonizing holocaust and in the face of threat or peril. In this speaking, or utterance, or statement, we see the inherent link of experience and thought, experience and idea. Experience as necessarily thinking, and thinking, as necessarily experience. In short, in the midst of life's limit experiences, its finitude, experience is thinking, as said above, a primal-intuitive thinking, before it is brought conceptually, structurally, and categorically, to understanding. And, to experience and think as such, to my mind, is a universal human phenomenon. In this regard, and as pre-understanding, in terms of my definition of understanding, we can equally say, that such thinking, such thought, or its ideas, is experience. It feeds into the understanding. In its primal experience, thinking or thought in this regard can also then be verbalized, or at least, asserts a force on a subject to 'search for words', or be at a 'loss of words', as we say. In the limit experiences of life, especially in life-threatening circumstances, such verbalisation, of experience,

${ }^{21}$ I have developed my notion of knowledge-power from Foucault's, as well as his notion of 'forces', 'relations of forces', and the 'relations of knowledgepower' or 'power-knowledge', and the outside of thought (cf. Foucault ([1970] 1982; [1971] 1972; [1975] 1979; [1976] 1981). Cf. also the various essays and interviews, collected in Faubion's Power (1994a), esp. 'The Subject and Power'; and 'Polemics, Politics and Problematizations' in Rabinow's The Foucault Reader ([1984] 1991). Also note Foucault's diverse examples in 'The Thought of the Outside' in his Aesthetics, edited by Faubion (1994b). The challenge is not merely to just assert the existence of power-knowledge or knowledge-power in the Colonial, or develop a vocabulary that aimed at analysing it in its complexity and the complexity of its effects á la postcolonial discourse/ criticism, but to constructively contribute to the developing of the emerging, new discourse, and related discursive practices. 
may aim to protest, to resist, but also to protect, shield, defend, maintain, and preserve life. This is the decolonial Truth, or Thought(s), or Knowledge(s), of the outside of the Colonial, or, at least, where we can find its roots - in experience. It is contingent, multiple, geographically dispersed over the globe, and historically spread over decades, as so many contingent constituents or components, of a dispersed or diffused and scattered thought. It appears in the interstices, the gaps, cracks, and openings or fissures of the Thought of the Colonial. In this sense, the Decolonial does not exist as a Thought or a Knowledge with a capital T and capital K. At least not as yet. It is refracted, and refracting, of the relations of forces of the knowledge-power of the Colonial Truth. Historically, it only exists as anecdotes, rumours and stories, as brief references in archives, and loose fibers and threads in dispersed memories. Collectively, one could, if you will, connect the dots, and discern certain patterns, certain repetitions, or configurations in this discursive multiplicity of this thought of life. This is thought as resistance - thought that resists death, ethnocide and genocide, and seeks to liberate life from the shackles, the bounded power of servitude and slavery, and perpetual imprisonment. The existential asserting of life in the face of life's limit experiences, becomes resistance to the brutalities of power-knowledge, and in our sense, a resistance to the Colonial. This resistance at the limit, occurs when the political object of life is provoked or incited, experientially as the asserting of life as freedom, the freedom of thought, and the freedom of action - life as the power of freedom. The outside of thought, then, in its Decolonial discursive sense, is never complete. It is always in the process of formation, not only socially, in terms of its diverse distribution of social formations, but also epistemologically, and historically. Analogically speaking, and more inclusively speaking, socio-culturally, covering the whole expanse of human endeavor, the work of thought, and therefore, the work of freedom is never complete. It is through some brief historically snapshots, that I shall trace this perception of the Decolonial, or what $\mathrm{I}$, for the purposes of this argument, call \#Decolonialenlightement, in this article ${ }^{22}$.

${ }^{22}$ In this endeavor, I want to expand the terrain or knowledge-power space that Edward Said (1994:79ff) termed, 'Africanism' (echoing his Orientalism, 1978). This is to access the colonial archive, but that contrapuntally (Said 1994:36ff,59ff,337ff). To get an idea of what he meant with this metaphor, listen to: https://www.youtube.com/watch?v=Uo1C603Nr24. This does not 


\section{The Decolonial}

As said, we need to locate the Decolonial on the outside of thought of the Colonial. In the face of the relentless and destructive colonization processes, the Decolonial, is constituted by a diverse array of experiences, but, closely related, 'thinking', or the intellectualizing of the colonizing experience. As such, 'thought', or 'intellectualisation' in the midst of the limit experiences of life, i.e. as living on the receiving end of colonisation, has, over time, constituted its own paradigm. And, in this section, I shall reflect on this, with specific historicisable references. Firstly, I briefly reflect on the historicisable dynamics and processes of the beginnings of colonization in South Africa. Secondly, I provide a few brief historicisable perspectives on the roots of the decolonial vis-à-vis the colonial in the process of formation. And, thirdly, I proffer a few conceptual perspectives which I regard as important for the notion of decolonial knowledge production.

\section{The Beginnings of Colonisation in South Africa and the Decolonial}

The main colonial practice through which the Truth/ Knowledge of the Colonial, was produced, is well-known, and available in many textbooks and publications from primary schools through university and beyond. It is that all knowledge about Africa has been produced by colonials, i.e. initially, the socalled seafaring merchants and their documentors (1500 - 1650), followed by the colonials, especially colonial governors who travelled 'to the interiors' of the colonies to 'observe' for themselves, and document their own observations of 'nature' but also the 'natural inhabitants', or indigenous populations of the countries $(1650-1850 \mathrm{~s})^{23}$. Closely related to them, were the similar colonial

mean that one should attend to what we here call the Colonial itself, but, its others, the thinking of the outside of the Colonial, in its contingency, and dispersion, as I here explain. (Please note that I do not use the notion 'Africanism' here, in the ethnographic sense that Ekpo [1995; and 2010], does, but in Said's sense.)

${ }^{23}$ The main aspect of this mode of knowledge production, which we may label the colonial 'travel-observe-document' mode of knowledge production is that it was conceptualized in terms of the intellectual registers and grids, 
officials and bureaucrats' observations and documentations, those by so-called travelers in the 'exotic countries' and 'around the world', and those by missionaries, that would follow especially after the 1795 founding of the London Missionary Society (LMS) in London, and the mission organisations and movements that would follow in its wake in the nineteenth century. From the perspective of the Colonial, we can call all these agents, the colonizing forces' 'data gatherers and interpreters', if not 'investigative journalists', during the colonial era ${ }^{24}$. All such data and knowledge production served the various purposes of colonization.

taxonomies, vocabularies, perceptions, concepts and philosophical presuppositions, or prejudices, then dominant in the country of European reception of such information documented in the colony. In other words, the empirically experienced and observed 'nature' or 'natural inhabitants' in the colonies, were articulated in terms of prejudicial conceptual taxonomies, schemata and configurations as evidence for the confirmation of already-held assumptions by European intellectuals in Europe. Even the speech of indigenous informants in the colonies were translated into the idiom (conceptually speaking) of the rising reading bourgeoisie, and reading and writing middle classes of Europe. This corpus of empirical knowledge, often presented in the form of travel diaries, and dated reports (such as annual submissions) which give the impression of dateable empirical experience and observation, were circulated in terms of the same conceptual configurations, European intellectuals coined in the first place for the 'seeing', 'observing', or 'perceiving', and understanding and interpretation of such data. As such, the colonial officials and bureaucrats, travelers and missionaries were only producers of the actual knowledge in a secondary sense. The prejudicial interpretive templates already existed, and even if they would be adjusted, and developed, this would often only happen in piece-meal fashion.

${ }^{24}$ The pragmatics of this process, was that the colonial officials or functionaries provided the data and that a wide array of academics and intellectuals in Europe ratiocinate on and further conceptualise such material, in terms of what we may call the general conception of the 'natural condition' of fauna, flora and humans. To this, we may obviously add European cartography, the mapping of seas and foreign lands, most specifically for control, and European settlement (cf. Bialas 1997). No doubt, the European white, male intellectual would also stand at the pinnacle of such a pyramid of produced knowledge, as the 
With regard to the beginning of the Colonial, we need to trace its history, then, or its pre-history to the culture-contact and cultural exchanges between Africans and colonials, on their own terms, i.e. Africans. This is the pre-history of actual colonial settlement at the Cape in South Africa, viz. the contacts of especially Khoikhoi and Xhosa, on the southwestern and southeastern parts of what would become first a Dutch and then a British colony later - from 1652 and 1795/ 1806 respectively $(1500-1650)$. This period roughly stretches 150 years, since when the Khoi and Xhosa encountered the Portuguese merchant ships (since c. 1500) and then the Dutch, British, and French merchant ships, until the Dutch settlement at the Cape in

ultimate example of the educated, enlightened, sophisticated and 'civilized'. The circulation of knowledge, was therefore circular. Intellectuals in Europe generated the ideas and matching concepts about the general natural (and human) condition, of life and culture (or 'custom') in the colonies. Observers in the colonies find the data that gave content to these ideas and concepts and their interpretations in the first place. They report such data back to the colonizing metropole, and intellectuals in Europe again develop their ideas and their related concepts further in terms of the continuous stream of ever new data supplied from the colonising frontiers. The circulation of knowledge was therefore circular, where the same prejudices would be founded or discovered, throughout the knowledge produced, whether in the metropole or the frontier. (Chidester's 2014 scholarly genealogical analyses provide ample evidence for this analysis.) Needless to say, this individual's other, would be the 'savage', the 'native' or 'uncivilized' of the colony - the non- or a-intellectual. More significantly for our purposes, though, is that that same knowledge was circulated back to the colonies, but now packaged as 'knowledge' for consumption in the education of the 'natives' or the 'savages', and destruction of the indigenous knowledge systems. Inherent in these, was, obviously, the prejudices, especially the prejudicial concepts, coined by the colonial intellectual and the imperial philosopher for, in the first place consumption in the metropole, and in the second place, the colonized other. In terms of idea and concept formation, we see, then, the colonized other, being subjected to and assimilating this knowledge, at least to the degree that one has to live in and survive the colonial. Mphahele's (1974:41) concept for this condition, as that of 'ambivalence', may yet prove very significant in our intellectualising and conceptualisation of the Decolonial, both past and present (cf. Smit 1998). 
$1652^{25}$.

Some material and research exist about the contact of Khoi and later Xhosa with Europeans, especially about the views and perceptions of the intermediaries and translators who functioned as go-betweens between indigenous populations and colonizing forces, since the $1650 \mathrm{~s}$ - all, for obvious reasons, produced from colonizing perspective, and embedded in the colonial archive. These references, allusions, often only brief and fleeting references to indigenous opinions and perceptions, constitute the beginnings of the Decolonial and have been referred to in existing research, of the last fiftyodd years to some degree ${ }^{26}$. In addition we need to engage the 'hidden transcripts' that survived in the sources, stretching roughly 300 years $(1650-$ 1950). Together, these are the traces of the decolonial corpus of the outside of colonial thought and practice ${ }^{27}$. The individuals on whom we do have reports

${ }^{25}$ For a magisterial more general collection of work on Africa so far, cf. KiZerbo (1981 -). Significantly, volume 9 is still outstanding, the one dealing with 'the recent history since decolonisation, the end of Apartheid and the place of Africa in the world'. (This might take quite a few volumes.) Cf. also Mazrui (1986; 2004; and 2002).

${ }^{26}$ In the latter half of the twentieth century in South Africa, since about the 1950s, some so-called liberal scholarship researched these aspects of colonial knowledge production, or what we may call, the alluded to, sometimes assumed, but also sometimes explicitly mentioned, provenance of such indigenous critique - contributing to what I have called the roots of decolonial thought. Much, though, even though it was reported about, in the idiom of the colonizer, remain unstudied as such. From these and related references we can further trace, some reports of Khoi and Xhosa perceptions, criticisms, and the nature of their resistance, dating from pre-colonial settlement, even as early as 1614 (cf. below).

${ }^{27}$ As is well-known, since the latter half of the 1800 s, we would see the rise of a new Black, mission-educated intellectual elite, who, at least to some extent, articulated and developed their own modern homegrown, local knowledge, in resistance to the knowledge production of and by the colonials. To some degree, they obviously had to censure their critique and resistance themselves, because they depended on financial assistance from abroad, and on the mission systems. As is well-known, some finances were raised by local missions themselves, through their own work - cf. Sales (1975); even though critical, 
in the sources, and the Truth and Knowledge-producing events they formed part of, form certain crystallizing points of thought, of decolonial thought, and thought as resistance, within the agôn of/ struggle against colonisation (cf. De Kock 1996:35f, drawing on Foucault [1982] 1994:342). We can take the date of the first half of the 1800s to around the mid-1850s as a date around which the intellectual resistance to the Colonial, started to crystallize in cultural products. This is also about the date, at which the final vestiges of Khoi resistance in the eastern Cape was crushed, both through physical violence and through British colonial policy, legislation, and what we may call, reservationism, or the hoarding of deterritorialised Khoi and Xhosa into specific geographical areas ('reserves') - the forerunners of what would later become South Africa's Bantustan system.

Different from other African countries, which were in many cases only subjected to the forces of direct colonization for a 'short' period of time - fifty or seventy years or so - for South Africa, the limit for this mode of knowledge production stretches roughly for about 450 years, from $1500-1950^{28}$.

they remained socio-cultural intermediaries, and had to develop their own discourse within the constraints of colonizing discursive formations.

${ }^{28}$ Apartheid, as an internal colonizing ideology, had a different dynamic. It was around 1950, that apartheid's own colonizing knowledge started to be produced ideologically, and to be put in circulation through internallyproduced ideological and repressive state apparatuses, within the colony itself. Amongst the many reports and books, the Tomlinson Commission Report (1955) is important in so far as it provided a trans-disciplinary blueprint for apartheid. What we have in this event, is the colonial outside of thought in this instance, in terms of the object of colonisation, developing a system, a schema, to colonise even better, and more efficiently than the existing Colonial at midtwentieth century South Africa at the time. This is why we see this continuous rising in intensity and the concentration of force and power in the one racial group (white) and the ever-increasing of its knowledge-power complex, with its militarized security bureaucracy in train, and its effects on the indigenous population through the police force and military (1950 - 1990). An added perspective is that with the National Party coming to power in 1948, and unilaterally declaring South Africa a Republic in 1961, it also dis- and replaced Britain effectively as colonial and colonizing power within the borders of South Africa. 
Concerning the colonial and colonizing archive, we then have 450 years of documentation of this brutal knowledge-power system in all its disciplinespecific and trans-disciplinary variety, as these were founded and came into being $^{29}$, together with institutions, organisations, strategies and tactics, and its imperially-negotiated and affirmed agreements on political ideology, political economy, and, suppressive white bureaucracy ${ }^{30}$.

We can then see that the main aspect of the Truth/ Knowledge of the Colonial was that of the circularity of its knowledge production, emanating from the metropole, gathering supporting data in the colony, the intellectual development or ratiocination of such data back in the metropole, and the backcirculation of the same knowledge, to the colony, but now as "native education ${ }^{31}$.

${ }^{29}$ For the first c. 150 years, cf. Huigen (2009). Of the six main humanities disciplines that came into being during the nineteenth century, 'Politics', 'Economics', and 'Sociology' were the most prominent. They cut across the European countries and the colonies. In addition, 'Orientalism' was founded to study the 'literate' Eastern religions, cultures and customs, and Anthropology, the 'illiterate' customs and cultures of Africa, South America and Australasia. Focused only on religion, we also see the formation of the socalled World Religions Paradigm (WRP), with initially only four religions included, e.g. Christianity, Judaism, Islam, and 'the rest' - what was also called the heathen and later traditional religions, polytheism, or the pagan religions (cf. Wallerstein 1996; Masuzawa 2005).

${ }^{30}$ For an interpretive analysis of Jan Smuts's racism, founded in the developing British science of ecology, see Anker (2001:41ff and 157ff). To my knowledge, how this manifestation of his racism is twinned and also embedded in the transcendental immoral rationalism of Immanuel Kant, still needs to be analysed. One is truly flabbergasted at the evidence that there has been no hope for equality that has been extended to the black nations of Southern Africa during the period 1910 - 1990, - not even by Smuts, the so-called leaderfounder of the Universal Declaration of Human Rights (UDHR).

${ }^{31}$ Up to the early 1950s, most of the actual education of the indigenous peoples of South Africa, was done in mission schools. At this point, so-called Bantueducation was formalized by the apartheid government, and a large number of 'mission' schools closed down, mainly for the reason that the education standards of their offerings were quite diverse and varied, and not properly 
Now, having pointed to actual referencing of indigenous perceptions in the inter-cultural interaction with the visiting Europeans, we need to ask the question as to the roots and nature of this knowledge. Because, if we can, we should, by doing so, uncover not merely an anti-colonial knowledge of resistance - where the colonized remain trapped in the colonial-anti-colonial binary - but the roots of the Decolonial.

\section{The Roots of the Truth/ Knowledge of the Decolonial in South Africa}

If we understand the student call for \#decolonialeducation correctly, it appears that the Colonial, is to a large extent still circulating between erstwhile colonial and imperial metropole and the erstwhile colony or postcolony. This remains a central assumption in much 'postcolonial theory' research emanating from both postcolony and metropole. Intellectually, the main paradigm questions, their objects of study, and their methodological procedures are not yet focused on and grounded in and for the realities of the postcolony. It is needless to say that we need to assert and practice the latter. As I argue in this article, this focus should, however be positioned within historical context, dating to African thought and practice from the first contacts with European settlers and colonizing forces. We can then ask as to where we find the roots of the Truth/ Knowledge of the Decolonial. And, as intimated above, there is again a simple, clear, obvious answer: in the gaps, the silences, the resistances, the brief references, and in the hidden transcripts of the colonisers' diaries, journals, reports, pamphlets, narratives, and books often published first in Europe and later in the colonies. In our case, we need to focus our attention on the nature of the thought, the ideas, the actual utterances, here, in the gaps, silences, the resistances, and in the hidden transcripts. Dating back to the 1500 s, we need to

benchmarked in current common parlance. As part of the apartheid ideology, though, from this point onwards, the political effects and the inherent ideological continuation of not only colonising knowledge, but now added to it, specifically apartheid-infused conceptual productions, would aim at the ever better and more comprehensive colonizing of black people through apartheidproduced knowledge-power (cf. Smit [2003]). Cf. also the important publications of Kallaway $(1984 ; 1988)$. 
ask this question with regard to the Khoi and Xhosa encounters with the representatives and negotiators of European merchant ships, later colonial officials, and even later, especially settler farmers.

Some work in actually pin-pointing or spotting these events, which, we could identify as events in thought, have been identified. And some have been researched, as I have intimated, since the late 1800s but especially since the 1950s, and of late, since 1994. As far as our task is concerned, and this with regard to the roots of this thought, our work, so to speak, is to continue to uncover and identify these events (their archival provenance), to identify the concepts or the actual thinking beginning with the Khoi and Xhosa, inside these specific events, and to intellectualise them in terms of the actual context or what we may call the contexture of these events ${ }^{32}$. The Decolonial, has its roots in the actual thought of the Khoi and Xhosa in the midst of the colonial encounter. We need to do this as specific historical moments in our history of thought. Historically, much of this has also been handed down through memory as part of tradition, and these are available from San rock art through traditions in actual living memory, researched by scholars of orality and memory studies for some decades now. The question though, in our specific decolonizing context, and similar to the Colonial, is how to account for this, in terms of process. My suggestion is that we see this in terms of what I want to call the process of socio-cultural encounter. The Decolonial, has its roots in the pragmatics of the socio-cultural encounter between Khoi and Xhosa individuals and representatives of the colonising metropole. And, I shall outline this process in this section.

Whenever I ask students about what they know of the colonizing and apartheid periods, with regard to indigenous interaction with colonising and apartheid officials and representatives, or forces, the most important concepts they normally use, are words indicating response or reaction, such as

\footnotetext{
32 This work is important for critique, in so far as it uncovers the conditions or circumstances under which human beings are not free, or the conditions that enslave them, and the conditions in the midst of which they speak out, raise their voice, and refuse to remain silent (cf. Horkheimer 1982:244). I have also found Gurwitsch's (1964:114) notion of 'contexture' helpful here. For me, it indicates not only a different, or conflicting perspective on the same event(s), or socio-cultural phenomena, but also imply a contextual, multi-dimensional depth of such a perspective or perception.
} 
'resistance to' or 'struggle against'. These are certainly apt. But, they usually only capture some aspects or certain phases of the socio-cultural encounters we are talking about. The nature of the encounters are actually more complex. Foundingly important for the Decolonial, they do not capture notions of actual thought, action, of agency, and concept coining, development in encounter, as a 'thinking-with', and as equal participants in encounter. I think that for our notion of the Decolonial, this 'thinking with', an 'equal thinking' in encounter, but, as said, with a different contexture, is essential. It denotes the equal participation in socio-cultural interaction, in what we may in general terms call, the early engagements of the modernisation processes of the modern world as it impacted us. Complimentarily speaking, this also means that there is not only one actor and one acted upon, but an equal to-and-fro action in the interaction. For our purposes, what asks for attention is the thought and action of the Khoi and $\mathrm{Xhosa}^{33}$. We need to capture the actual thought and action of the Khoi and Xhosa, in the actual, historicisable moments or events of interaction. And, this needs to be intellectualised. Such intellectualisation, will produce the Decolonial, but, we need to see it in terms of what I called a process or the processes of socio-cultural encounter, above. Obviously, in their specific historicisable events, and movements, 'resistance' and 'struggle' too, have their own thought and action, their own intellectualization of socio-cultural interaction, inbuilt in them. But, let us move on to explicate the basics of this process.

If, in interaction, one is not threatened by violence up front, from the beginning, then the basic human instinct is to interact with others, also unknown others, on the basis of an equitable value, that of mutual curiosity and respect, pending the awareness of the attitude or stance of the other towards the self. This was not different with the Khoi and Xhosa's numerous encounters with representatives of passing merchant ships for the 150 years prior to European settlement at the Cape. This attitude was the principle of all these

33 You will notice below, that this stance, or standpoint is historically appropriate, and at the root of the Decolonial. It allows us to assert the historically accurate and truthful agency, actions and initiatives of the Khoi and Xhosa. No-one needs to be reminded that colonization and apartheid denied such equal participation, and what we may call participatory development of what we now know as global modernity, in the world system. 
numerous interactions $\mathrm{s}^{34}$. In terms of the actual exchange of goods, in these precolonial actual interactions, we can also assume that the basic value of 'equilibrium' that has been identified as the basic value in barter economies, also determined these interactions (cf. Binswanger (2012:9). The value of equilibrium, means that the 'price' in exchange, were perceived by the two bartering parties to be of equal value. This means, that the representatives of the merchant ships acquired the Khoi and Xhosa cattle, sheep and goods they needed for their ships, and the Khoi and Xhosa received the valuables that the ship merchants offered in exchange as part of what they valued, viz. the beautification of themselves and their Khoi and Xhosa wives, and children. Excepting drought, and internal competition for veld for grazing their livestock, this was also the principle of the barter economy amongst Khoi and Xhosa clans and groups in the interiors of South Africa. This system of interaction continued well after the colonial settlement (1652), and, to be precise, the year 1700. But, we are running ahead of ourselves.

The first indication that we have from the historical record, that this equilibrium was disturbed, was with the taking of a Khoi mediator or translator, in this barter economy, called Coree, to England, to learn English, so as to better 'translate' between merchant ship and Khoi cattle and sheep or livestock owners. On his return to the Cape in 1614, he conscientised the Khoi about the fact that what they receive in return for their cattle and sheep that they barter away to the merchant ships, was not the same, price- or value-wise. In other words, he learnt that the merchant ship barterers knew that what they barter with was not equal in value to that which they received. According to historical records, this immediately caused an 'inflation' of the prices of Khoi cattle and sheep at the Cape, with the Khoi now asking more goods in their bartering with the merchant ship representatives. This happened in 1614, before colonial settlement ${ }^{35}$.

${ }^{34}$ Even though we can assume this perspective, there is also evidence that, in time, such encounters, due to a growing hostility to European attitudes and actions, both the Khoi and Xhosa became not only suspicious of them, but also aloof and distrustful. Why would one cooperate, in one's own subjugation? ${ }^{35}$ In order to understand this value-clash, and also as this would continue to impact indigenous economy and culture, during the long three hundred years of external colonization by The Netherlands and the British (1652 - 1910), Baudrillard's (1974) distinctions between four types of value in society, is 


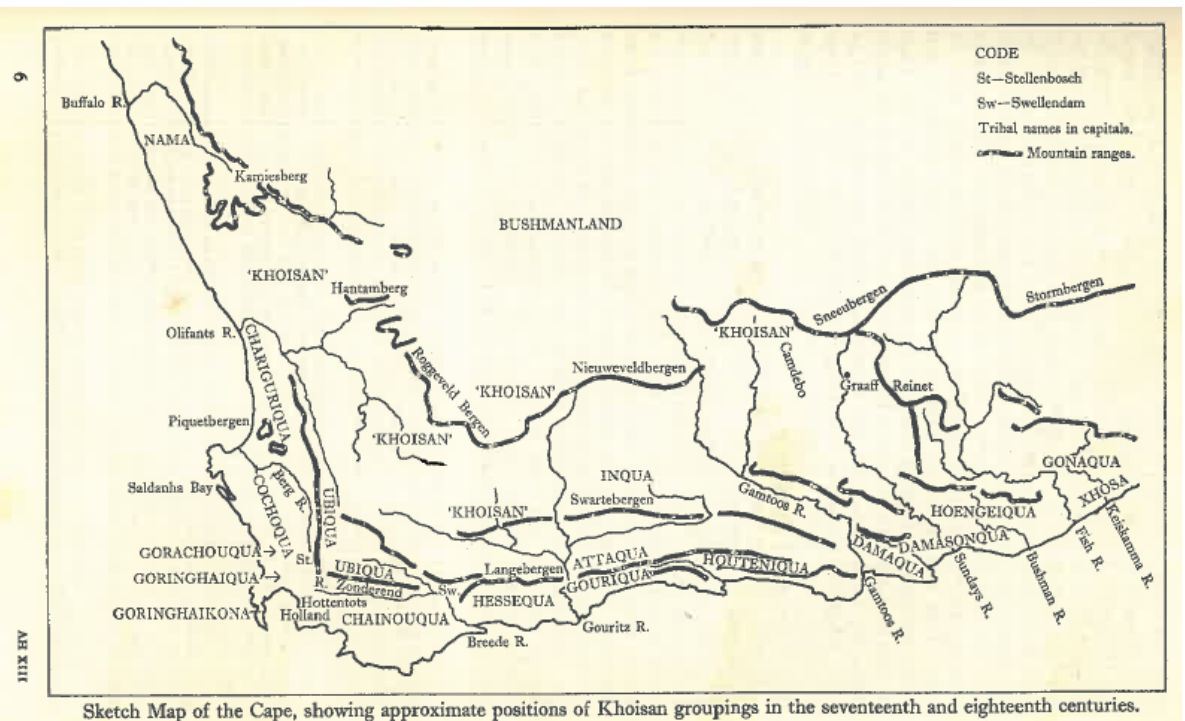

\section{Khoikhoi clans or more inclusively speaking, Khoikhoi social formations at the time of the beginning of colonization, in 1652 (cf. Marks 1972:65)}

This dynamic continued into Dutch settlement, with numerous other mediators and barterers in the inter-cultural exchanges, conscientising the Khoi livestock owners in the same way, not least a member of the now well-known Krotoa's (or Eva's) own family. There was one additional decisive event though, that in time, would terminally destroy the barter economy between the Khoi and representatives of the merchant ships, and also lead to what we may call Khoi

relevant, e.g. sign value and symbol value, in addition to use value and exchange value. In this analysis, colonial use value far outstripped indigenous use value, even though bartered products had sign and symbol or ritual value. Cf. also Coetzee (2000) for his analysis of this phenomenon in the South African farm novel. 
ethnocide ${ }^{36}$.

Five years into settlement, by 1657 , the Dutch colonial administrator at the Cape decided that it has become too expensive and erratic in trade, to depend on Khoi cattle and sheep in the Western Cape, and also the livestock that they bartered in the interior on behalf of the merchants, and then brought to the Cape. The Western Cape Khoi have actually become very shrewd (or 'sly' as some authors would have it) in this, in so far as they bartered young animals from their fellow Khoi in the Cape interior, but only bartered older animals away to the colonial company, building up their own livestock numbers. And, at least one Khoi livestock owner became quite rich in the number of livestock he owned. It is said that within a few years, he ammased over 2000 heads of cattle in the Western Cape, by the mid-1650s. So, this brought the colonial administrator to release company officials to become stock farmers and agriculturalists to produce and sell their produce to the company, as food for the passing ships. Whereas the earlier intellectual response of the Khoi was to increase the price of livestock in the barter economy, they here saw that their very livelihood was now threatened. They then confronted, Van Riebeeck, and when he did not give way, they attacked this first group of settler farmers in 1659. Shortly afterwards, in 1660, and far from being suppressed, they sought peace though, in the expectation that trade would resume. It is reported that the Khoi believed that their continuing problem was that the Dutch were,

... taking every day ... land which had belonged to them from all ages and on which they were accustomed to depasture their cattle. They also asked whether, if they were to come into Holland they would be permitted to act in the same manner (in Marks 1972:64).

So, the realization amongst the Khoi that they were being dispossessed of their land, and that they were in the process losing their veld for livestock farming, was consciously realized quite early in the colonial settlement. And, this was the pattern that repeated itself throughout the colonization of South Africa.

\footnotetext{
${ }^{36}$ I use the notion of ethnocide here, since it correctly designates the destruction not only of an ethnic group, but also the culture of that group as a distinct cultural formation.
} 
First we have the colonial demarcation of geographical areas for settlement and settler farming, with the actual settlement of farmers following these decisions, and independent of whether there were indigenous people living on the land, or farming their livestock there. This, the first 'war' with the Khoi, or from indigenous perspective in South Africa, the first war of resistance, was the result of what in today's parlance we would call a colonial 'land-grab', being the first step, and initiating what would in the end become the large-scale deterritorialization of the indigenous peoples of South, and Southern Africa.

Against this background, it is clear, that Khoi attack of the settler farmers did not happen out of the blue so to speak. It was based on the intellecttuallisation of a process of socio-cultural encounter, the developing of a critique, and the voicing of critique. As said, such intellectualisation already dates from the increase in prices in the early part of the seventeenth century before Dutch settlement. This strategy of the Khoi was handed on to the next generation - it became part of collective memory - and they applied it too, in this case, in the 1650 s, to increase the price of younger animals. So, for around 160 years of encounter of the merchant ships, and the first few years of Dutch settlement, Khoi provided the cattle and sheep meat for passing ships. To certain degrees, we can say that what we have here, is the equal participation of the Khoi in what was then happening through what became known in centuries to come, one of the basic precursors of the modernisation of the world, in this instance, through trade in the mercantile system. The Khoi were not aor non-intellectuals in this participation, but equal partners as livestock herders in their own right. Furthermore, they did some comparative analyses: whether it would be accepted by the Dutch, if they (the Khoi) would do the same to them in Holland, as what the Dutch was doing in theirs, i.e. to take their land, the land that 'had belonged to them for all ages', and the land of their livestock. In addition to recognizing the breach of reciprocity in the social value of 'equilibrium' in a barter economy, we here see the Khoi recognizing the beginnings of the colonising deterritorialisation of indigenous people(s). In this, too, they recognised the breaching of a central value in the presumed equity in intercultural interaction, viz. the respecting of property, in this instance, landed property. This analysis and assessment, ratiocination and judgement, came from existential experience, and the rational detection of a certain historical causality, with a certain future consequence - the loss of land to colonization.

In terms of process, we can then say that we have contact, sociocultural exchange in terms of an equality value in exchange, the raising of 
suspicion of dis-equilibrium, collective conscientisation of unfairness (or injustice), and collective action, namely attack. So, there was a whole history and memory transmitted into this, what became known as the first KhoikhoiDutch war (1659) with settler colonialism. This was followed with another two such wars, in short succession, with the similar dynamics, but with one difference. Now, the Dutch attacked the Khoi to rustle their cattle and sheep from them, in 1673, and then again from 1674 - 1677. In this last three yearlong raid, it is said that the Dutch rustled over 5000 head of cattle from the Western Cape Khoi and from the Khoi in the interior. More importantly though, the Dutch would begin a process of land dispossession or the deterritorialisation of the Khoi in conjunction with cattle raids. The way in which they did this was to proclamate a certain territory for settler settlement and farming (to produce livestock and food for the passing merchant ships, and the settlers themselves), and then to settle company officials released from their employment, to farm as for the benefit of the company, or to import settler farmers specifically for this purpose, from the Netherlands for such settlements. This was done through violence, and irrespective of the existence of Khoi settlements, and Khoi grazing veld, in these territories. This history repeated itself over another more than 150 years. First the Dutch colonial governments, and then the British colonial governments (from especially 1806 onwards), would proclamate a certain territory for settlement, and irrespective of Khoi, and later Xhosa livestock owners and farmers' presence in the area, would then forcibly settle Dutch and later British farmers in these areas. This was a progressive process which started in 1657 with the first 'free burghers' or officials released from company duties, for the purpose of livestock farming and agriculture.

It is also from this time onwards that we can speak of a developing history of Khoi resistance, the outside of Colonial Thought, and Knowledge. Such resistance though was futile, because the Khoi could not compete with the power exerted on them through the government-sanctioned violence of commandos, and guns, but also the relentless settlement of farmers in their ancestral territories, that basically crowded them off their land, confiscated their livestock, rendered them landless, and divided them from their subsistence. Through need, they were by default, forced to either labour on settler farms or become unwilling landless sojourners, reverting to living off the veld, reverting to hunting and gathering beyond the colonial borders, and raiders, or in the discourse of the time, 'banditi' and fugitives. The resistance, 
however, remained and continued. At times, it would break out into open war, the so-called frontier 'rebellions ${ }^{37}$ of the Khoi, in which they were joined by some Xhosa ${ }^{38}$.

Noteworthy is that the release of the Dutch officials for farming, was that the first few years of Dutch settlement at the Cape did not 'fulfil ... the financial expectations' of the Lords XVII, in charge of Dutch trade with the

${ }^{37}$ Maybe it is more correct to see these not as 'rebellions', as the scholarly literature term these interactions, but as armed struggle against the illegitimate occupiers of Khoi lands. Similarly, these should not be seen as 'frontier wars', as from the perspective of the colonizing forces, or, even 'rebellions' - as if by citizens - but as the early beginnings of armed defensive action against the violence of colonization.

${ }^{38}$ If I may use the license the specific topic of this lecture, and this plenary's theme gives me, I would like to suggest that in brief, we need to build a systematic model of the rural, village agricultural and herder economies of the Khoi and Xhosa, along the lines of Scott's (1976) theorizing of the 'peasant moral economy'. Here, we find that it is based on a 'subsistence ethic', and an agrarian quest for 'safety first' (Scott 1976: Chapter 1). Related to these, we have the prime moral codes of 'social reciprocity, social choices, preferred systems of tenancy among rural populations, and attitudes toward taxes' (Scott 1976: Chapter 2). It is against the background of these values that we need to build models about the nearly 500 years of moral resistance to colonization both external (1500 - 1950) and internal (1950 - 1990) - in South and Southern Africa. And, wherever resistance matured into open rebellion, these need to be explained in terms of models that resonate with those of Scott (see esp. Scott 1976: Chapters 3 - 5), as these were sparked by the basic value of 'subsidence security', the 'subsistence ethic' and a 'safety first' morality, all of which were threatened variously, ranging from physical harm and murder, to taxes that did not heed the moral economy of 'what was left' after tax. Following a period of model building, and clarifying the realistic portrayals of the socio-cultural resistances in the history of our last 500 years, we should be able to come to writing coherent social histories of these 500 years, from verified indigenous perspectives in the historical record. There has been many initiatives in this direction, but I think a more co-ordinated programme of action is required. Some of the best in this regard, are the studies by Bundy, and Van Onselon, e.g. New Babylon (1982a), New Nineveh (1982b), and The Seed is Mine (1996). 
east. The releasing of company officials for purposes of settlement and farming, was one of their 'remedies' or interventions in this scenario. Concomitantly with this strategy, the Dutch would first approve 'grazing rights' to settlers, beyond the initial settlement boundaries, followed by new geographical demarcations, with borders, of these 'uninhabited' land, and actual settlement. In this way, Stellenbosch district was established, with a boundary between the Cape and Stellenbosch proclamated in 1711. And, remember, the establishing of 'districts' were not for the well-being of the inhabitants of the land, but for purposes of colonization, for colonizing increasingly better.

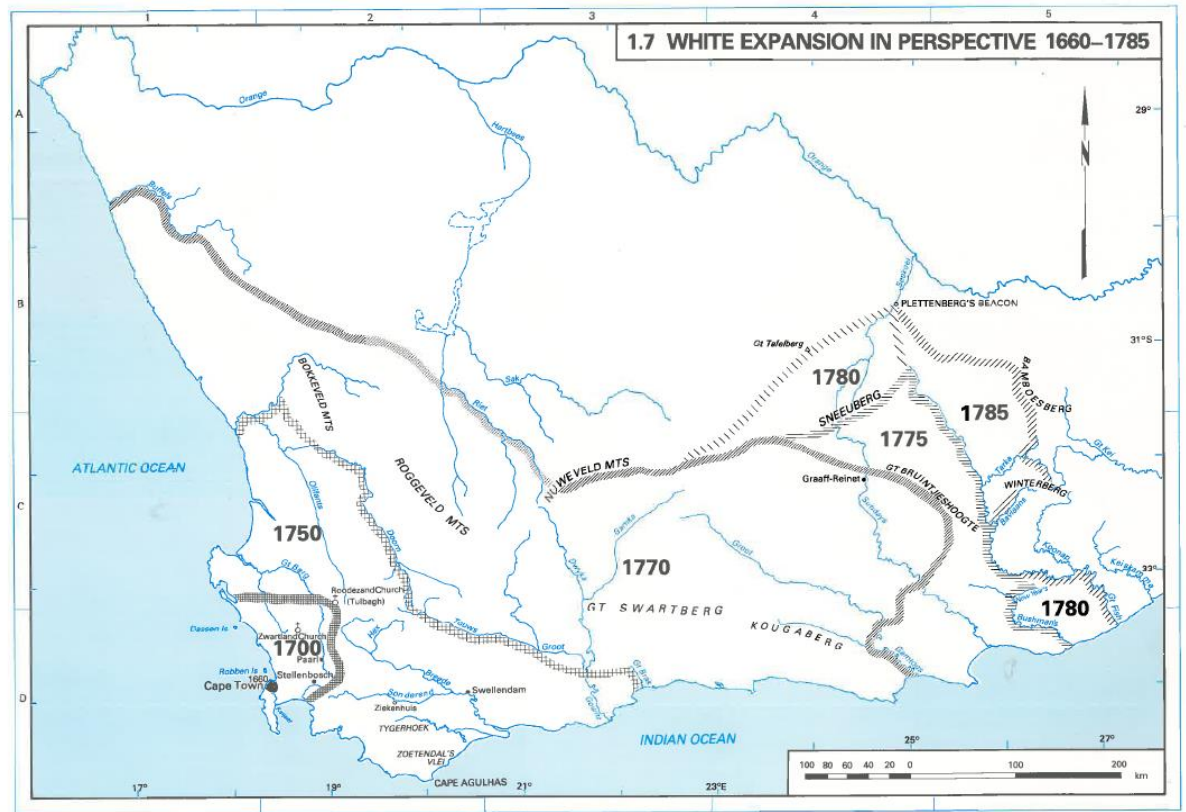

Dutch Settler Expansion and Proclamations (1660 - 1785) (cf. Bergh \& Visagie 1985:15)

White colonists, though were already moving far beyond the administrative reach of the Stellenbosch Drostdy, and, white settlement beyond the loosely-defined border, was gathering momentum. In addition to the purchasing of stock from the settlers, the administration at the Cape sold 'grazing licenses', and put a new 'land tenure' system in place, the so-called 
'loan-farming system'. Both these two systems spurred on the 'migration of White stock farmers into the interior'. In order to gain 'more effective control' of the ever geographic expanding of settler colonization, the Dutch government proclamated the Swellendam district in addition to the Stellenbosch district on 31 August 1745. The drawing of boundaries via proclamations of the Council of Policy at the Cape ${ }^{39}$, continued into the latter half of the eighteenth century, with some tentative lands attached to the Northeast of the Stellenbosch and East of the Swellendam districts in the 1770s. During 1778 - 1780, Governor Van Plettenberg 'negotiated ${ }^{40}$ ' new lands and borders with the Xhosa, viz. the 'Gwali Chiefs', with the view to proclamate a new district in 1780. The district of Graaf Reinet was proclamated on 26 August 1785, and the boundaries proclaimed on 19 July 1786 (Bergh \& Visagie 1985:2-13).

Throughout the wave-on-wave of the increasing geographical incremental colonisation and occupation of land, with the proclamations, merely trying to assert bureaucratic colonizing control over the process, the Khoi were pushed ahead of this wave of White settlement. This caused much conflict between Khoi clans and fellow social formations, for grazing lands and span the whole 150 years since the 1660s. This was leading up to a final conflict with the colonising settlers. All historical sources agree that, following the proclamation of the Graaf Reinet district, where the Khoi were caught in the middle between advancing settler farmers and the Xhosa to the East, the period 1785 - 1795 was one of the most vicious, and bloodiest, in the destruction of Khoi settlements and the extermination of the Khoi. As the Settler farmers found themselves in competition with the Khoi for grazing veld

39 This was the main colonizing apparatus used for land dispossession and deterritorialisation. Its socio-cultural history and the history of its developing discourse still needs to be written. Cf. Liebenberg (n.d.) for a very brief Introduction, and for 'Resolutions of the Council of Policy at the Cape' for the archive of the actual resolutions.

40 There is much evidence that, this whole history of the so-called colonizing force's 'negotiating', or in some cases, even bartering of land and settlement was a sham. Not only was the actual meetings that took place where such agreements were reached, a mere pretense, but also their reportage. In this regard, the whole colonial, and apartheid history field that report on or narrate such negotiations, should be re-written. Wherever it happened, the Khoi and Xhosa saw it for what it was - land dispossession and deterritorialisation. 
for their livestock, and the Khoi, in turn, with the Xhosa to the East, the settlers settled in the newly proclamated district of Graaf Reinet violently. Khoi clans and settlements were decimated. Those Khoi who survived, especially women and children (men were mostly shot), had to work on the settler farms as herders, or 'servants'. Often, because they would try to escape, in chains.

It is in the midst of this turmoil that rumour reached these areas about the British occupation of the Cape. At this point, the settlers revolted against the British, and the Khoi's hopes were raised for a better dispensation. So, with regard to the Khoi, what happened next? ${ }^{41}$

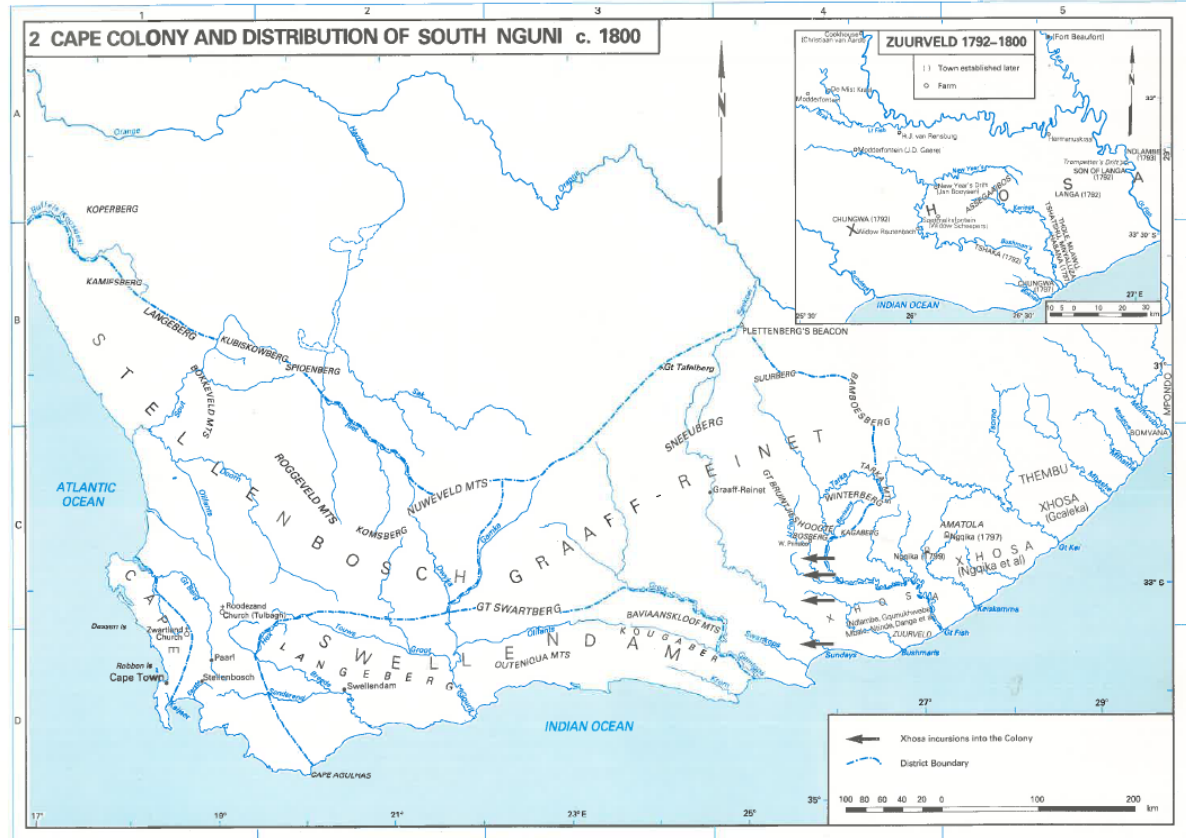

Physical map indicating significant mountains, rivers and the four colonial districts c. 1800: Cape, Stellenbosch, Swellendam and Graaff Reinet (cf. Bergh \& Visagie 1985:17)

${ }^{41}$ I am not dealing with the so-called settler or Boer rebellion (1799) under Marthinus Prinsloo against the British here. 
During the first British occupation of 1795 - 1803, there was just one notable proclamation, that of Governor George McCartney, 14 July 1798. It did not add any land to the colony during this time. It merely confirmed, or more closely charted the borders of the then districts, in order to manage them better.

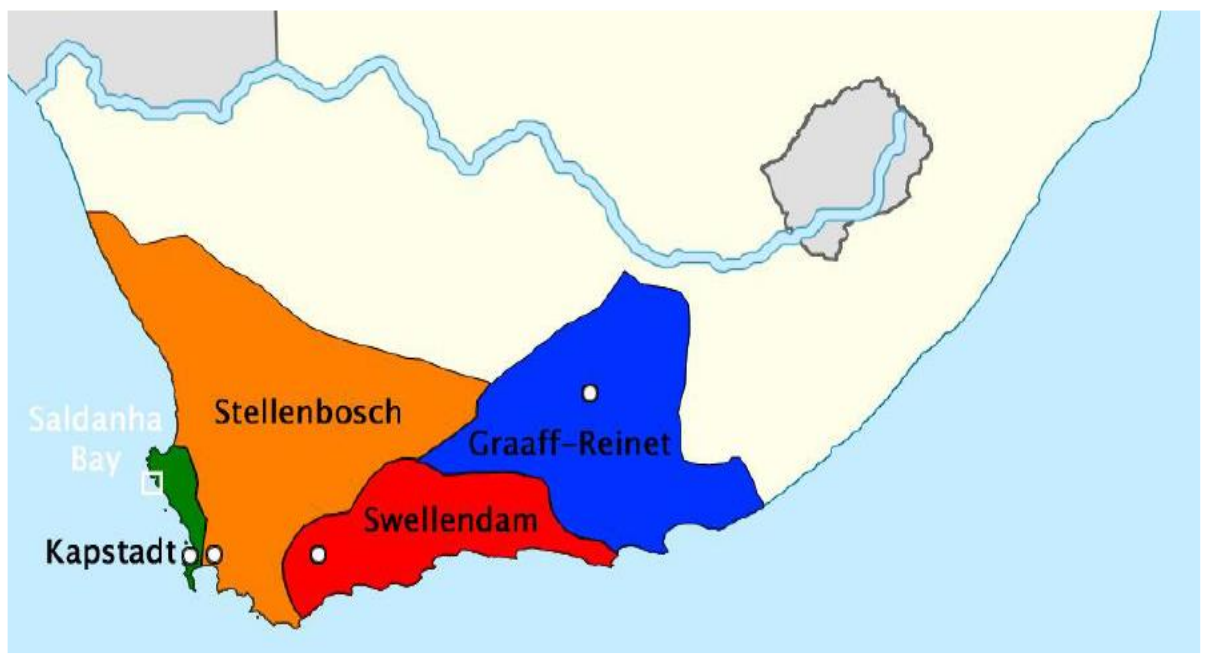

\section{Political map of the four colonial districts c. 1800: Cape, Stellenbosch, Swellendam and Graaff Reinet (Freely available on the internet)}

Ultimately, after the so-called final Khoi rebellion (1799 - 1803), the Khoi succumbed. Already during the one hundred and fifty years of the historical process of deterritorialisation, many Khoi fled to the Orange river in the North. Some clans established new communities, such as the Griqua, or joined the Xhosa in the East. In time, they would also here, though, be overcome, together with the Nama and later Tswana in the Northwest and North respectively, and Xhosa in the East, as these social formations became colonized and clustered together into reserves according to the British colonial governments' relentless proclamation of territories to be occupied by settlers, and of the resettlement of Khoi and Xhosa in so-called 'reserves' ${ }^{42}$. Throughout these processes, though, resistance, struggle and intrinsic critique remained,

${ }^{42}$ The recent publication of a second edition of Mamdani's Citizen and Subject 
was handed on through generations, and became part of a supra- or trans-social formation resilient collective resistance movement with numerous strands and threads of a collective struggle memory in South Africa. The downside of all this, was obviously the acculturation, and, in the case of the Khoi, ethnocide, and later some Xhosa clans. In many cases, though, we can see the cultural resistance, and resilience, even into today's continuation of indigenous cultural traditions and practices. But let us turn more specifically, to what has become known as the last stand of the Khoi, or the so-called 'third frontier war' (out of nine).

\section{The Significance of the 1799 - 1803 Khoikhoi Rebellion in the History of Thought}

In the aftermath of a failed and crushed Dutch settler farmer rebellion against the newly-arrived British care-taker occupying force of the Cape, the Khoi put there hopes in the British to not only curb and arrest the relentless expansion of Dutch settler farmer encroachment on Khoi lands, but to reverse this trend. They also petitioned the colonial government to prohibit settler atrocities against Khoi farm workers (so-called servants and herders), the raiding of still existing Khoi settlements and their livestock, within the colony, and its buffer zones bordering Xhosa lands, and to prosecute perpetrators. However, it soon became obvious that this was not happening. Instead, the British continued with precisely the same practices as the Dutch, i.e. to proclamate land and then to settle settler farmers in Khoi lands despite them living on and off it, and to allow the raiding of both Khoi and Xhosa for their livestock. In terms of the then expanding imperial mercantile and emerging capitalist economies in Europe, and their commerce and trade with the East, one can understand that

(1996), which deconstructs not only British and French colonizing governments' indirect as well as direct rule, but also that of apartheid as the generic form of direct colonization, is a welcome broadening of the debate on these matters, at our current conjuncture, especially in terms of how indirect rule reproduced racial and 'tribal' identities - also adopted as policy towards the Francophone postcolonies, by the post/colonial French. Cf. also Mazrui (1973; 2002); Mafeje (1971); Saul (2008); and Mbembe (2017). 
the 'invisible hand' of merchant and capital accumulation would continue to need resources for its ships passing the Cape. The relentless, unremitting, and competitive growing British imperial economy (competing esp. with France), and also in terms of its then rising ascendancy at controlling the trade by sea, needed ever more resources for its ships passing the Cape. So, rather, than halting the process of settler farming atrocities and the raiding of Khoi livestock, the whole complex process of deterritorialisation, and especially of forcing Khoi to work on settler farms, in some cases, as the history record attests, and enchained to prevent escape, was stepped up. When this became clear to the Khoi, this information spread within a few months amongst the Khoi disenfranchised, oppressed and exploited farm workers throughout the Eastern Cape, primarily amongst the Khoi working on the settler farms. This lead to a large-scale desertion of farms. Some Khoi moved into Xhosa lands, and a large number went to squat at Graaf Reinet. Barrow reports in 1801, that there were over 8000 Khoi, men, women and children at Graaff Reinet when he arrived there in 1798. Here, they were threatened by Boer attacks and mass murder. Evidence suggests that this resulted in nearly all, more than 7000 Khoi, fleeing into Xhosa lands between Barrow's visit, and Van der Kemp's return from Ngcika in 1801, for protection. Here, and together with the Xhosa, they formed and organised for the so-called third frontier war against the British and its commandos. The war would last four years, from 1799 - 1803.

Right at the beginning of the war, in 1799, also indicating the rational reason for the Khoi deserting settler farmer employments, Barrow reports Klaas Stuurman, the main Khoi 'rebel' leader at the time, to have said:

Restore ... the country of which our fathers have been despoiled by the Dutch, and we have nothing more to ask. We lived very contentedly before these Dutch plunderers molested us, and why should we not do so again, if left to ourselves? (in Newton-King 1981: 16).

As said, in the limit experiences of life, lived experience is thinking, and thinking, lived experience. The work of memory, and conscientisation of injustice and unfairness, in the exponential and additive loss of land is evident here. If we interpret Barrow's census data from 1798/ 1798, we see that the Dutch progressively pushed the Khoi off their lands, through the same process (1657 - 1787) - issuing 'grazing rights' to the expanding settler livestock 


\section{Johannes A. Smit}

farmers ${ }^{43}$, the proclamation of land by the Council of Policy at the Cape, forceful settlement of settlers, and then subduing the Khoi to become servants and herders ${ }^{44}$ of Dutch livestock on their own ancestral lands. Much of this same livestock was also accrued through the raiding of Khoi animals. So, in many instances, Khoi ended up herding their own livestock, but now for settlers. In the Graaf Reinet district, this dynamic was especially started with the Dutch proclamation of the Graaf Reinet district in 1787, as said. At this time, according to the historical record, there were independent Khoi (clan) settlements in the area, where Khoi allowed settler farmers to share grazing velds in their land. After 1787 though, the district was formed and cut up into farms onto which settler farmers were forcefully deployed as part of colonising settlement practices. This decade-long process continued, and were in fact intensified with British occupation in 1795 (even though a minority of Khoi also benefitted from better trading conditions at what is NMM today). This dynamic, their loss of land and livestock, and their being forced to become sojourners on their own lands as servants and herders of the settlers, caused the Khoi's mass desertion of settler farms to Graaf Reinet, lead to the statement by Stuurman, and the 'border war' of 1799. The overarching and principle reason for all these border wars, was the progressive forceful occupation of land and the final deterritorialisation of the Khoi, and later Xhosa.

It was in the midst of the beginning of this war in 1799, that Johannes van der Kemp, the first London Missionary President of African missions arrived in the Eastern Cape. He was determined to start a mission for the Xhosa, beyond the colonial border among Ngqika's people. However, after more than a year there, he was not allowed to do so, and returned to Graaff Reinet. What is of interest to us, for our purposes of tracing some of the events of the Decolonial at this time, is the interaction of some of the Khoi, including Stuurman, with Van der Kemp. On his way to Xhosa country. As he passed through the Graaff Reinet district, he encountered some of the Khoi fleeing from settler persecution during the Boer rebellion, but in the company of some

${ }^{43}$ From the historical record, it is evident that the issuing of 'grazing rights' was mostly 'after the fact', when the migrant-settler farmers have already occupied land for their livestock.

${ }^{44}$ In Smit (2016b), I have pointed out that Khoi in the employment of Boors were basically treated as slaves. This is also confirmed by Barrow (I 801:46 amongst others). 
trekking settler farmers (presumably searching for grazing veld for their animals). He recounts that in response to his attempt to 'evangelise' them, and because some of the settlers did not want to join the Khoi in a religious meeting, he held one separately for some Khoi. Here, they sang, from their own choice, and very convincingly, he says (!), obviously in Dutch, a hymn from Psalm 118 in the Hebrew Bible. The words, are as follows (cf. Van der Kemp's journal for August 29, 1799; Newton-King 1981:24).

\begin{abstract}
A Song of Victory
${ }^{1} \mathrm{O}$ give thanks unto the LORD: for he is good because his mercy endureth forever .... I called on the Lord in my distress: the Lord answered me, and set me in a large place. The Lord is on my side; I will not fear; what can man do unto me? My Lord taketh my part with them that help me. It is better to put trust in the Lord than to put confidence in men. It is better to trust in the Lord than to put confidence in princes. All nations compassed me about: but in the name of the Lord will I destroy them .... They compassed me about like bees; they are quenched at the fire of thorns: for in the name of the Lord, will I destroy them .... Thou has thrust sore at me that I might fall: but the Lord helped me .... I shall not die but live, and declare the works of the Lord .... The stone which the builders refused is become the head stone of the corner ... ${ }^{45}$.
\end{abstract}

From this reported event, we can see that some Khoi must have been inculcated in the Christian culture of the settler farmers, as well as one of their main cultural objects, viz. The Bible. They have obviously appropriated some ideas, central to Christianity, for themselves. In this instance, they have

${ }^{45}$ This translation provides some perspective on the Dutch religious ideas that Khoi appropriated, given their own conditions of oppression and exploitation. The original, was presumably a print version of Peter Dathleen's 1566 translation of the French hymnbook, Book of Psalms, which also reportedly had a wide usage in the Netherlands during their eighty year War of Independence $(1568$ - 1648) with the Spanish occupying forces. It could have even been the so-called 'State rhyming' of the same, of 1773, if Van der Kemp indeed brought this version of the Psalms to be sung, with him to the Cape (cf. http://www.holandiabez tajemnic.pl/?page_id=4382 \&lang=en). 
appropriated this text as a text from the coloniser's own cultural goods, for asserting their own social analysis and thinking about their own socio-cultural condition and liberation. In principle, we do have here, decolonial thought, thought of resistance, and of the seeking of divine intervention and divine justice, but also thought of victory, articulated in song. This was just one of the constitutive elements of what would in time become part and parcel of struggle ideology, in which the Bible would play a central role in Southern Africa ${ }^{46}$. What is important too, is that their choice was a song that outlines a process that leads from oppression (their own experience at that time), through confrontation, resistance, struggle, and defensive battle to victory. And, according to some historians, they nearly succeeded in driving the settler farmers out of the Eastern Cape during this time. Vandeleur, the commander dispatched by the Governor to quell the 'rebellion', reports as much when he likened the 'rebellion' to the most successful slave revolt in history, that of San Domingo, in Haiti, in 1791, and that secured Black independence (in NewtonKing 1972:27). Another significant analogy, to the Khoi 'rebellion', is that of Commisary J.A. de Mist's 1802 judgement of the 'border farmers' in the Graaf-Reinet district, viz. that they 'seem to realise in their conduct, the tragic ideal of [Thomas] Hobbes, Bellum omnium contra omnes' (War of all against all). The Khoi (and San), in his description, have become 'the most dangerous enemies of the Colony, and a continual guerrilla warfare of defence and attack has to be waged' against them (De Mist [1802] 1920:254).

During the Khoi 'rebellion' of 1799 - 1803, the Xhosa would join the Khoi, but not only during this period. As they themselves, took up the battle to defend themselves and their lands, against the continuously intruding, and encroaching settler farmers, the Xhosa stood together amongst themselves, different Xhosa clans normally in competition with one another, for grazing lands, in order to, in the words of one Xhosa Chief, 'not be broken up as the

${ }^{46}$ In this regard, Justin Ukpong (in Mugambi \& Smit 2004: 36ff) makes the important distinction of using the Bible as a 'weapon or a tool'. In the agonistic socio-cultural resistance of and struggle against colonisation and apartheid, numerous so-called 'Western' cultural objects, media, and related malleable cultural goods, would not only become objects of contestation, but also weapons as well as tools in the struggles for freedom, not least the Christian Bible. For the Bible, cf. West's recently published The Stolen Bible (2017). 
Khoikhoi were' (Marks 1972:78) ${ }^{47}$. In the midst of these battles though, Van der Kemp's intervention, was to petition the British colonial government to cease sending commandos against the Khoi and Xhosa. From his own $17^{\text {th }}$ century knowledge of the European Enlightenment, he would assert the freedom of the Khoi, that they constitute a 'free nation', champion the restoring of their land, or at least a 'place' that they could call 'their own home', as well as 'perfect equality', in all senses of the word, with the settlers. In his writings, he often calls the latter, 'these inhuman wretches', and 'un-Christian inhabitants' of the 'frontier' zones, even though they called themselves 'Christians' in lieu of the religious self-perception in Europe before the constitution of the World Religions Paradigm (cf. Smit 2017a and 2017b, forthcoming; and Smit 2016a) ${ }^{48}$.

For the Khoi, the aftermath of this war was bleak, to say the least. With the retrocession of the Cape back to the Dutch (the Batavian Republic) on 01 March 1803, according to the Treaty of Amiens (1802), the Khoi discontinued or suspended the war effort, pending their assessment of the attitude of the new Dutch government towards them. Again, they hoped for an improvement of their condition. And, similar to what they did with the British in 1795, they petitioned the new Governor Janssens and his envois and administrators - now with the additional support of Van der Kemp, and his fellow missionary Read - in the border region to stop the atrocities of the frontier settler farmers against

47 There is much evidence of how rumors, speculations and opinions of the progressive aggressive and violent systematic encroachment of white settler farmers on traditional ancestral lands spread and circulated among indigenous groups in South Africa from the earliest settlements of the Dutch at the Cape. ${ }^{48}$ For the 'positive' sense in which I use the notion of 'enlightenment' here, and below, cf. Anderson (2014); Dubois (2006); Ducheyne (2017); Griswold (1999); Israel (2001; and 2006); Lazarus (2004); Muthu (2003); Paquette (2009); Porter \& Teich (1981); Prakash (1995); and Shklar (1969). The essays in Carey and Festa (2009) cover quite a number of aspects of this perspective on the notion of the Enlightenment as both a West-European 'eighteenth century phenomenon' and as a 'concept that bears on modern ... formations'. I think it is important to recognize the 'tensions and disparities' within Enlightenment thought, that it does not constitute a 'unified construct', also, with regard to the Philosophical canon, and that, for both the Colonial, and in our contemporary modern, and modernizing period, the Decolonial. 
the Khoi. Yet, to no avail. Again, they were to be disappointed. The Dutch reconfigured the existing districts, and added two more (cf. below).

As part of the outcome of the war, Van der Kemp won a bleak spot, where he could found his mission station, with some 200-odd Khoi following him. This became the famous Bethelsdorp, and for many Khoi and Xhosa, a symbol of 'white', missionary resistance and critique of colonialism, and the frontier settler farmers. Most Khoi had to return to labour on settler farms, as servants and herders, continuing to be subjected to the inhuman conditions there. Some stayed amongst the Xhosa, and on the new mission stations that would be established by a variety of Christian missions in frontier regions and beyond the colonial frontiers, and would in decades to come cooperate with the Xhosa in their own wars of resistance and survival ${ }^{49}$.

\section{Three Decolonial Reflections}

In the three sections above, I have reflected, with reference to historicisable events, on what we may call the beginnings, process, and roots of the decolonial, in terms of my theorizing of the notion of the Decolonial. The bulk of this argument has been focused on the notion of the 'decolonial' as a domain of thought on the outside of 'the' Colonial. In this section, and only proffering three brief observations, or reflections, I want to point to a kind of thinking outside this colonial-decolonial dichotomy. To think, and theorise the Decolonial is extremely important, as I have argued. What, in the long run, or in terms of 'structural time', is even more important, and that is to even think outside this box.

${ }^{49}$ Part of the hidden transcript of so-called Khoi defeat, their cessation of hostilities, their returning to work on farms, and apparent resignation to their subjection and 'fate' to the settlers, are present in historians' and authors' perplexity at their apparent docile, return to the different forms of slavery against which they rebelled in the first place. No less than a Khoi leader such as Klaas Stuurman, counts among these. In his case, though, he requested a farm of his own - in fact his own ancestral land - which was granted. His brother, David, though would continue the battle, was captured, served time on Robben Island, escaped with Nxele (Makana) - an escape orchestrated by two fellow inmates, Johan Smit and Hans Trompetter - was captured again, and banished to Australia where he was released from prison in the early $1820 \mathrm{~s}$, but shortly after died (cf. Malherbe 1980). 


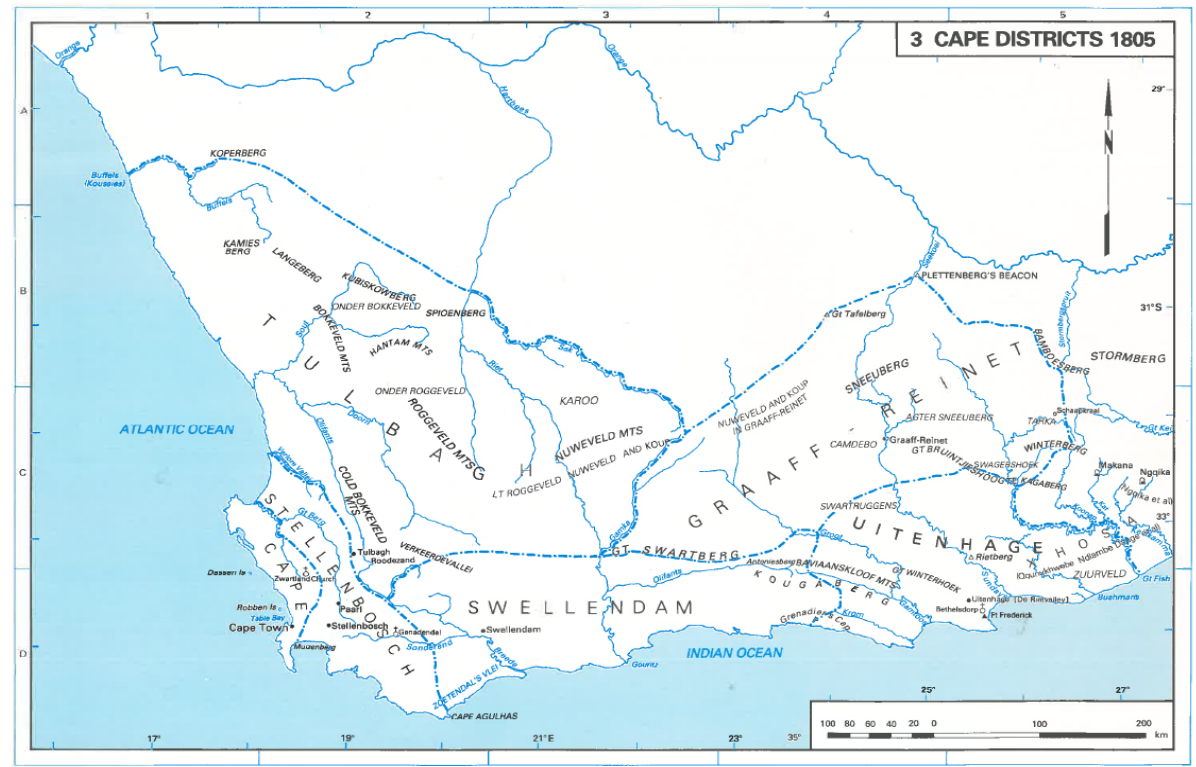

During their occupation of the Cape, the Batavian Republic (the Netherlands), proclamated two additional districts, viz. the Districts of Tulbagh and Uitenhage (1805) (cf. Bergh \& Visagie 1985:19).

Firstly, we need to be sure about our perception of time, history, that is, with regard to the Colonial. And, here, I want to propose that we follow Basil Davidson's suggestion, when he said:

African development has run in an unbroken line from its distant origins until the present. The Africans are the children of their own past in just the same sense as all other major groupings of humankind, so that even those intrusions or interruptions which have seemed most traumatic and significant of change, such as the colonial period, were in truth no more than episodes or stages in a long continuity of growth (Davidson 1969:3).

This is equivalent to Wallerstein, following Braudel (if we make some minor adjustments), distinguishing between the time of the event, episodic, 
cyclical, or ideologico-chronological time, and long-term 'structural' time (cf. Smit 1999). In this sense, the period of colonization, much longer in South Africa than other parts of Africa as pointed out above, with much more longterm trauma and acculturation, was an episode in its continuous cycles of time. In African context, and with different dates attached to them, we may distinguish between the pre-mercantilist period (earliest days to $17^{\text {th }}$ century); the mercantile period $\left(17^{\text {th }}\right.$ century to 1800$)$; integration into full capitalist system (1800 - ); colonization (variant dates in different African regions - the present) (Amin 1971: 503 - 524); the post-colonial, etc. Following, Ajayi (1968:194-196) we can assert that this does not mean that Africa was not severely impacted by a variety of forces effecting socio-cultural change and underdevelopment. We may mention Africa's history of slavery, and with the arrival of colonisation, the progressive loss of sovereignty; the introduction of colonising and patriarchal Christianity; the similar effects of Islam in colonial, and post-colonial Africa; western education; western social, religious and political ideas; and the acculturation of African practices that were adjudged incompatible with European [Christian] traditions. More importantly though, is that African participation in the equal and participatory development of the modern world system was hampered, stultified, blocked, preempted, and negated - not least through arsenals of legislation ${ }^{50}$.

${ }^{50}$ The most important views on underdevelopment are still those of Walter Rodney (cf. Smit 2014), and in South Africa, the empirical studies of Colin Bundy (1984; 1987a; 1987b; 1988) of the Eastern Cape 'peasant farmers' and the 'peasant economy' of the Xhosa farmers, that outperformed the colonists at the time, as well as the numerous studies of Terence Ranger. This was before the laws were made that prevented the Xhosa from even renting their own ancestral lands from colonial settlers back, in order to farm, and in so doing, outperforming the settlers. It was also before the time of the reserve legislation that would move Xhosa clans finally into the dreaded 'reserves', signaling their final succumbing to deterritorialisation, and the loss of their ancestral lands. In this sense, the study of the Decolonial, is a negation of the negation of the colonial, or a production of knowledge precisely where there was a 'colonial negation of development', and the production of knowledge in a space that is focused on the integrity of the social and socio-cultural facts of African developmental realities, on the one hand despite the colonial repression and negations, throughout colonial history - in terms of its own resistance, 
Secondly, as briefly demonstrated in this article, there have been many manifestations of thought, of critical thinking, of thinking in resistance, in all the colonies of the world, not least in South Africa. Such thinking, has formed part of many forms of resistance and critique, and to various degrees, have engaged the Truth or the Knowledge of the Colonial. This is what I have called, lived experience as thinking, forms of oppression, of enchainment, of having to function within the limits and limitations of unfreedom, of incarceration, forms of confinement, captivity, internment, detention and continuous threats of death and other limit experiences. These were present in the most illiterate of societies, the most uneducated and ignorant or subaltern - as individuals and as socio-cultural communities. And, these have spanned many geographical areas and historical events, and episodes, from the beginnings of colonial contact, through the rise of resistance and resistance memory, to the thought inside the thought of the many anti-colonial wars of resistance. Inherent, and asserting inside this resistance, was that of life, the indomitable will to live, demonstrated, by the resilience of those who resisted, and struggled, and, ultimately experienced victory, at least politically, that is.

Thirdly, we need to position ourselves with regard to the digitally globalizing world of the last two to three decades. In this, there are many sociocultural, knowledge and information ebbs and flows the world over, none of which are synchronised. We need to position ourselves with regard to how we could draw the most benefits from these movements, not least in developing our own decolonial truths and knowledges. In this regard, Amilcar Gabral (1970) used the notion of 'critical assimilation'. This is where interpretive communities, engage globally accessible available knowledge(s) and information for their own benefit. This needs to be done critically, through critical thinking, and through critical assimilation, integration, and incorporation into our own productions of knowledge and truth. Needless to say, he Truth(s) and Knowledge(s) that we produce or participate in producing, need to empower our own communities, but also centrifugally contribute to and add to the world-historical development and accumulation of Truth and Knowledge. Yet, as said, as we participate in this work of thought, we are continuously challenged to think the outside, even of this thought that we are in the process of constructing.

resilience, hardiness and optimism and enthusiasm. For the latest views, cf. Mphofu (2017), amongst others, in Oloruntoba and Falola (2017). 


\section{The Decolonial as Enlightenment}

As mentioned above, we still use the concept 'colonial' in the notion of the 'decolonial', and not something else. Moreover, despite the diversity of European countries and their diverse forms and practices of colonization, but also a diverse array of retro-impacts such colonization processes have had back in these countries, both in their state-power and economic-labour complexes, at the epistemic level, there has been some form of discursive unity or homogeneity. Parallel and actually feeding off but also into the diverse colonisation processes and projects, was the so-called European Enlightenment. Immanuel Kant captured it in his December 1784 'What is Enlightenment?' essay, as something that was happening. It was a reflection on the present moment, or in Foucault's (1984) view, a very significant event in the history of thought, as a reflection on what he termed the 'history of the present'. It was not something that Kant envisioned or even propagated. Rather, his essay, at that point in time, captured what has been happening for some years, maybe even decades, in Europe, and more particularly, in the Germany of the time, in the present moment.

In his famous, 'What is Enlightenment?' essay (December 1784), Kant captured some of the key ideas of the notion of 'enlightenment' thought and practice - praxis. For him, those who are enlightenened, have a commitment to and practice the principle of 'sapere aude' (cf. above). Similar to how other enlightenment thinkers of his time insightfully and perceptively captured and conceptually expressed essential understandings of both human and geopolitical processes such as morality, wealth, or nationalism, he did so for what enlightenment thought itself entails. For enlightenment thinkers, he averred, there are no truths to be arrived at through the tutelage of others, whether priests, religious books or doctors. Truth, or knowledge, is arrived at by individuals using their own capacity to think or reason, i.e. to question existing received dominant knowledge, texts and related practices, and to find answers for yourself. Needless to say, such 'answers' or knowledge produced through independent thinking, was also widely disseminated in the rising tide of an increasingly very competitive knowledge market, the market of ideas.

Ideas, as we have seen from 1776, and 1789, could bring about revolution, or to a lesser degree, bring about a variety of forms of civil and personal transformation. Writing in the Prussia of King Frederick the Great (1740 -1786), an 'enlightened' monarch himself, who encouraged the German 
enlightenment - as did many other royals in the Europe of the late seventeenth and eighteenth centuries - Kant sounded a warning though. In order to put some restraint on this 'thought-free-for-all', especially in terms of its potential geopolitical consequences, and potential uprisings and revolutions, Kant advised, 'Argue as much as you want and about what you will; only obey!' In his case, and for the readership of the Berlinische Monatschrift (Berlin Monthly) in which his piece appeared at the time, Kant's view was that people should continue their enlightenment thought and practice, but that the limits for such praxis, were set, by obedience to an enlightened regime. Following the Holocaust, Hannah Arendt's view was that we change this form of obedience, even of an enlightened regime, to read 'Niemand hat das Recht zu gehorchen', no-one has the right to obey, and, to love the world, amor mundi (cf. Arendt 1955). For some, this would mean that if there is a rule or limit, to problematize it, but, eventually, to break it. I think, that in the history of Decolonial thought, this is what happened, and that is why we do need, a decolonised, and decolonising Africa, and African intelligentsia ${ }^{51}$.

\section{Conclusion}

I have tried to outline some seminal points, in terms of which one could start to research the actual roots of the content of the Decolonial in South Africa. There is much already that comprise this archive from the second half of the $18^{\text {th }}$ century, and to some limited extent, earlier. More needs to be done to push the history of Decolonial thought in South Africa, back in time, to some of its

${ }^{51}$ I do not want to count heads, and not counting how previous generations have verbalized the decolonial enlightenment, numerous scholars have come to the fore over the last number of years, that represent and address precisely this issue in South Africa or Southern Africa, viz. Mabogo P. More, Mokong Simon Mapadimeng, Sabelo Ndlovu Gatsheni, J.T. Lebakeng, M.M. Phalane N. Dalindjebo, Milton Nkoane, Siphamandla Zondi, and Dube Bekithemba amongst many others. My point is that we need to move beyond the rhetoric and engage the archival and (collective) memory archive in my reconstruction proposals, more constructively. Rhetoric and related \#decolonial movements will come and go, but the importance of the actual (re-)construction of the variety of puzzles of the requisite social history of South Africa dating from, and linking up with pre-colonial times, is imperative. 
earliest roots. This lecture provided only a brief glimpse of this work that mostly still needs to be done. As said, such thinking, whether in history, with regard to the historical event of thought, or the present, is exterior to Truth and Knowledge, rooted in colonizing processes, and as canonized and circulated. This is true for the Colonial but also the post-Colonial, and, the Deolonial, in the process of formation.

With regard to the point at which I began this article, viz. the brief overview of the different steps the South African Department of Education has taken on the way to realise a fully decolonized education, ranging from preschool to university and postgraduate research levels, since 1995/ 1996, I want to make just two points that have relevance in our current conjuncture. Firstly, in 2013, the South African Government published a not insignificant White paper about tertiary education, viz. the White Paper for Post-School Education and Training: Building an Expanded, Effective and Integrated Post-School System. As you can glean from the title of this white paper, the intentions of government is to 'expand' the post-school system, together with an increase in the in-built 'effectiveness' of the programmes offered in this expanded system, as well as create the possibilities for greater 'integration' in these programmes. I shall not engage these matters here, because of space and time ${ }^{52}$. Suffice to point out that, significant for us, in our context, and region, is the statement that, it says,

In light of the need to increase enrolments, the DHET has decided that predominantly contact universities may choose to offer distance programmes, provided that effective quality-control measures are in place. The onus will be on each institution to justify a particular programme offering in terms of its mission and overall profile as well as the nature of the programme concerned. The DHET will also encourage all universities to expand online and blended learning as a way to offer niche programmes, especially at postgraduate level, to those who are unable to attend full-time programmes, either due to their employment status or their geographical distance from a campus (p. 51).

${ }^{52}$ But see especially the 'Background and Challenges' and the 'Main Policy Objectives' (pp. 1-10). 
Vis-à-vis previous decisions, this White paper now opens the doors for distance education, by formerly residential universities. This creates the opportunity for those university progammes and programme niches, that are at the forefront of the production of decolonized knowledge formations, to open the doors of culture and learning to those who could not previously afford to study at residential universities in South Africa, and further afield. Institutionally, this could yet prove an important apparatus to turn the tide of the hegemony of colonizing knowledges and truths, still prevalent in our systems of thought.

Secondly, the insitutionalisation and instrumentalisation of such an apparatus, would be of no use, if its content and research-led teaching and learning methodologies do not centrally integrate, what I have termed the emerging Decolonial in this presentation, together with its ingrained accompanying fostering of an actual critical and creative thinking focused on our specifically African conundrums, and globalizing challenges. As far as content, I shall not say anything more, here, except to point to the historicising example that I gave. With regard to thinking, we need to kindle the kind of thinking that Kant, in his own time and context, based on the notion of the more than two millennial old maxim, Sapere Aude, to 'dare to know', to 'dare to think for yourself' or more generally, to 'dare to be wise'. If we integrate procedures that stimulate such thinking in our online programmes, we shall not only facilitate a liberation from the colonizing 'self-incurred tutelage', that we have inherited from the past, but most importantly, contribute to the emergent decolonized generation of intellectuals that can take up the numerous responsibilities of a collective engagement of knowledge production with regard to local issues, but also on a world-wide front. This is the unfinished work of freedom, the labour of thought as potential and possibility, as an unfinished task. And, if we are not part of this yet, I have provided a few very brief pointers about the kind(s) of focuses and processes one could engage, amongst others. And, that is also why I quoted Foucault at the beginning of this article - 'Thought is freedom in relation to what one does' ${ }^{53}$. A fuller version of this quote reads:

Thought is not what inhabits a certain conduct and gives it meaning;

53 A parallel interesting exercise is to also read Foucault's 'What is Enlightenment' in terms of his commentary on Kant's version, but also his own reflections on the same topic in his own time and context, in Rabinow (1984). 
rather, it is what allows one to step back from this way of acting and reacting, to present it to oneself as an object of thought and question it as to its meaning, its conditions, and its goals. Thought is freedom in relation to what one does, the motion by which one detaches oneself from it, establishes it as an object, and reflects on it as a problem.

As a personal approach to Truth and Knowledge and especially Truth and Knowledge construction, I think this captures something about what our approach to what we do, but also what we experience, could be. Therefore, I have called this article, \#DeclonialEnlightenment ${ }^{54}$.

\section{Acknowledgements}

* I want to thank Prof. Gregory Kamwendo, Dean of the Faculty of Human and Social Sciences, University of Zululand, for inviting me to give a lecture based on this paper, at the $8^{\text {th }}$ Zululand Humanities and Social Sciences Conference, 18 - 20 October 2017, Richards Bay (cf. footnote 1).

* In addition, I want to thank the University of KwaZulu-Natal for the sabbatical during which I could do the research and write-up this article, amongst others.

* I would also like to extend my sincere gratitude for the multiform assistance and help that I have received from Ms. Faith Bhengu, UKZN Principal Librarian (Durban), Ms. Celeste Johns, Circulation Supervisor, Mr. John Timms, Circulation Desk (Interlibrary Loans), and Mss. Shanitha Bhim and Bronwyn Tayler, Circulation Desk (Pietermaritzburg).

\section{References}

Ade Ajayi, J.F. 1968. The Continuity of African Institutions under Colonialism. In Ranger, T.O. (ed.): Emerging Themes of African History:

${ }^{54}$ Note: The only reason why I have used the hashtag - \# - as part of this title, is to make the notion or, idea, decolonialenlightenment, as a combination of two words, indexible, as well as searchable, amid the large amounts of data available online, including the rising number of \#words and \#concepts, especially those related to \#decolonial. 
Proceedings of the International Congress of African Historians held at Dar es Salaam, 1965. London.

Amin, S. 1972. Underdevelopment and Dependence in Black Africa: Its Origins and Contemporary Forms. Journal of Modern Afrian Studies 10,4: $503-524$.

Anderson, M.S. 2014. Europe in the Eighteenth Century: 1713 - 1789. Fourth Edition. London \& New York: Routledge.

Anker, P. 2001. Imperial Ecology: Environmental Order in the British Empire, 1895 - 1945. Cambridge: Harvard University Press.

Appiah, A. 1992. In my Father's House: Africa in the Philosophy of Culture. London: Methuen.

Arendt, H. 1955. Amor Mundi. In Rose, S. What Does it Mean to Love the World? Hannah Arendt and Amor Mundi. Transformation 27 March 2017. Available at: https://www.opendemocracy.net/transformation/samantharose-hill/what-does-it-mean-to-love-world-hannah-arendt-and-amormundi. (Accessed on 27 September 2017.)

Barrow, J. 1801. Travels into the Interior of Southern Africa. Volumes I and II. London: T. Cadell and W. Davies. Available at: https://books. google.co.za/books?id=Ly11AAAAMAAJ\&printsec=frontcover\&sourc $\mathrm{e}=$ gbs_ge_summary_r\&cad=0\#v=onepage \&q\&f=false. (Accessed on 06 October 2017.)

Baudrillard, J. [1974] 1981. For a Crtique of the Political Economy of the Sign. St. Louis, MO: Telos Press.

Bergh, J.S. \& J.C. Visagie 1985. The Eastern Cape Frontier Zone 1660 1980: A Cartographic Guide for Historical Research. Durban: Butterworths.

Bialas, Z 1997. Mapping Wild Gardens in South Africa. Essen: Verlag Die Blaue Eule.

Binswanger, H.C. 2013. The Growth Spiral: Money, Energy and Imagination in the Dynamics of the Market Process. Heidelberg: Springer. DOI 10.1007/978-3-642-31881-8_2. Available at: file://C:/Users/Smitj/ Downloads/9783642318801-c1.pdf. (Accessed on 20 August 2017.)

Bhabha, H. 1994. The Location of Culture. London: Routledge.

Booysen, S. 2016. Fees Must Fall: Student Revolt, Decolonisation and Governance in South Africa. Johannesburg: Wits University Press. Braudel, F. [1958; 1969] 2009. History and the Social Sciences: The Longue Durée. Review 32,2: 171 - 203. Available at: http://uwch-4.humanities. 
washington.edu/Texts/BRAUDEL/History\&the-Social-Sciences-The\% 20Longue\%20Duree-40647704. (Accessed on 10 November 2017.)

Bundy, C. 1984. Land and Liberation: The South African National Liberation Movement and the Agrarian Question, 1920s - 1960s. The Review of African Political Economy 11,129:14-29.

Bundy, C. 1987a. History, Revolution, and South Africa. Cape Town: University of Cape Town Press.

Bundy, C. 1987b. Remaking the Past: New Perspectives in South African History. Cape Town: University of Cape Town Press.

Bundy, C. 1987c. Hidden Struggles in Rural South Africa: Politics and Popular Movements in the Transkei and Eastern Cape, 1890-1930. James Currey.

Bundy, C. 1988. The Rise and Fall of the South African Peasantry. James Currey Publishers.

Cabral, A. 1970. National Liberation and Culture. Available at: http://www. blackpast.org/1970-amilcar-cabral-national-liberation-and-culture. (Accessed on 28 September 2017.)

Carey, D. \& L. Festa (eds.) 2009. The Postcolonial Enlightenment: Eighteenth-Century Colonialism and Postcolonial Theory. Oxford: Oxford University Press.

Chidester, D. 2014. Empire of Religion: Imperialism and Comparative Religion. Chicago: The University of Chicago Press.

Coetzee, A. 2000. 'n Hele Os vir 'n Ou Broodmes. Grond en die Plaasnarratief sedert 1595. Pretoria en Kaapstad: Van Schaik en Human en Rousseau.

Council on Higher Education (CHE) 1998. Pretoria: Council on Higher Education Available at: http://www.che.ac.za/. (Accessed on 01 September 2017.)

Davidson, B. 1969. A History of East and Central Africa to the Late Nineteenth Century. New York.

De Kock, L. 1996. Civilising Barbarians: Missionary Narrative and African Textual Response in Nineteenth Century South Africa. Johannesburg: Witwatersrand University Press. Available at: http://ufdc.ufl.edu/ AA00019564/00001/1j. (Accessed on 20 November 2017.)

De Mist, J.A.U. [1802] 1920. The Memorandum of Commissary J.A. de Mist, Containing Recommendations for the Form and Administration of Government at the Cape of Good Hope, 1802. Cape Town: Van Riebeeck Society. 
De Sousa Santos, B. 2016. Epistemologies of the South and the Future. From the European South 1:17-29.

Dubois, L. 2006. An Enslaved Enlightenment. Rethinking the Intellectual History of the French Atlantic. Social History 31,1,February: 1 - 14.

Ducheyne, S. 2017. Reassessing the Radical Enlightenment. Routledge.

Ekpo, D. 1995. Towards a Post-Africanism: Contemporary African Thoughts and Postmodernism. Textual Practice 9: 121 - 135.

Ekpo, D. 2010. Introduction: From Negritude to Post-Africanism. Third Text 24,March,2: $177-187$.

Foucault, M. [1970] 1982. The Order of Things. An Archaeology of the Human Sciences. London: Tavistock. Available at: https://is.muni. cz/el/1423/jaro2013/SOC911/um/Michel_Foucault_The_Order_of_Thi ngs.pdf. (Accessed on 24 November 2017.)

Foucault, M. [1971] 1972. The Archaeology of Knowledge and the Discourse on Language. New York: Pantheon. Available at: https://monoskop. org/images/9/90/Foucault_Michel_Archaeology_of_Knowledge.pdf.

(Accessed on 21 November 2017.)

Foucault, M. [1975] 1979. Discipline and Punish. The Birth of the Prison. Sheridan, Alan (trans). London: Penguin. https://zulfahmed.files.word press.com/2013/12/disciplineandpunish.pdf. (Accessed on 15 November 2017.)

Foucault, M. [1976] 1981. The History of Sexuality. Volume I: An Introduction. Hurley, Robert (trans). Harmondsworth: Penguin. Available at: http://www.24grammata.com/wp-content/uploads/2013/ 06/foucault_sexuality_24grammata.com_.pdf. (Accessed on 30 November 2017.)

Foucault, M. 1982. The Subject and Power. In Fabion, J.D. (ed.): Power: Essential Works of Foucault 1954 - 1984. Volume 3. London: Penguin Books. Also in: Critical Inquiry 8,4: 777 - 795. Available at: http://www.unisa.edu.au/Global/EASS/HRI/foucault_-_the_subject_and _power.pdf. (Accessed on 12 October 2017.)

Foucault, M. 1984. What is Enlightenment? In Rabinow, P. (ed.): The Foucault Reader. New York: Pantheon Books. Available at: https://www.libarts.colostate.edu/leap/wp-content/uploads/sites/24/ 2017/01/Foucault-What-is-enlightenment.pdf. (Accessed on 15 October 2017.)

Foucault, M. [1984] 1991. Polemics, Politics and Problematizations. In 
Rabinow, P. (ed.): The Foucault Reader. Harmondsworth, Middlesex: Penguin. Available at: http://www.naturalthinker.net/trl/texts/Foucault, Michel/Foucault,\%20Miche1\%20-\%20Polemics,\%20Politics\%20and \%20Problematizations.pdf. (Accessed on 16 December 2017.)

Foucault, M. 1994a. The Thought of the Outside. In Fabion, J.D. (ed.): Aesthetics: Essential Works of Foucault 1954 - 1984. Volume 2. London:

Penguin Books. Available at: https://monoskop.org/images/c/cf/Foucault _Michel_Aesthetics_Method_and_Epistemology_1998.pdf. (Accessed on 05 October 2017.)

Foucault, M. 1994b. Power: Essential Works of Foucault 1954 - 1984. Volume 3. Fabion, J.D. (ed.). London: Penguin Books.

Griswold, C.L. 1999. Adam Smith and the Virtues of Enlightenment. New York: Cambrdige University Press.

Gurwitsch, A. 1964. The Field of Consciousness. Pittsburgh: Duquesne University Press.

Higher Education Qualification Framework (HEQF) 2008. Pretoria: Council on Higher Education Available at: http://www.dhet.gov.za/Policy\%20 and $\% 20$ Development $\% 20$ Support/Frequently\%20Asked\%20 Questions $\% 20$ on\%20the\%20High\%20Education\%20Qualifications\%20Frame work\%20(HEQF).pdf. (Accessed on 01 September 2017.)

Higher Education Qualification Sub-Framework (HEQSF, Revised) 2013.

Pretoria: Council on Higher Education. Available at: http://www.che.ac. $\mathrm{za} /$ sites/default/files/publications/PUB_HEQSF.pdf. (Accessed on 01 September 2017.)

Houghton, D.H. The Significance of the Tomlinson Report. Africa South. (January 1957). Available at: http://disa.ukzn.ac.za/sites/default/files/ pdf_files/asjan57.4.pdf. (Accessed on 08 November 2017.)

Horkheimer, M. 1982. Critical Theory: Selected Essays. New York: Coninuum Publishers.

Huigen, S. 2009. Knowledge and Colonialism: The Eighteenth-century Travellers in South Africa. Leiden: Brill.

Iser, W. 1972. The Reading Process: A Phenomenological Approach. New Literary History 3,2,On Interpretation I, Winter: 279-299.

Israel, J.I. 2001. Radical Enlightenment: Philosophy and the Making of Modernity, 1650 - 1750. New York: Oxford University Press.

Israel, J.I. 2006. Enlightenment Contested: Philosophy, Modernity, and the Emancipation of Man, 1670 - 1752. New York: OUP. 
Jansen, J.D. 1999. Why Outcomes-based Education will Fail: An Elaboration. In Jansen, J.D. \& P. Christie (eds.): Changing Curriculum: Studies on Outcomes-based Education in South Africa. Cape Town: Juta Publishers.

Jansen, J. 2010. The Enduring Legacy of OBE. Timeslive 22 July. Available at: https://www.timeslive.co.za/ideas/2010-07-21-jonathan-jansen-the-en during-legacy-of-obe/. (Accessed on 14 January 2017.)

Kallaway, P. (1988). From Bantu Education to People's Education. Cape Town: UCT.

Kallaway, P. (1984). Apartheid and Education. South Africa: Ravan Press.

Kant, I. [1784] n.d. Was ist Aufklärung? Available at: http://gutenberg. spiegel.de/buch/-3505/1. (What is Enlightenment? English translation by Mary C. Smith. Available at: http://www.columbia.edu/acis/ets/CCREAD/ etscc/kant.html. (Accessed on 08 September 2017.)

Ki-Zerbo, J. (ed.) 1981 -. General History of Africa. Volumes I - VIII. London:

Heinemann Educational and UNESCO. Available at: http://www.sa history.org.za/sites/default/files/file\%20uploads\%20/general_history_afr ica_i.pdf. (Accessed on 23 January 2018.)

Lazarus, N. 2004. The Cambridge Companion to Postcolonial Literary Studies. Cambridge.

Liebenberg, H. n.d. Introduction to the Resolutions of the Council of Policy of Cape of Good Hope. Kaapstad: Government Printers. Available at: http://www.tanap.net/content/activities/documents/resolutions_Cape_of _Good_Hope/Introduction_English_Resolutions_of_the_Council_of_P olicy_of_Cape_of_Good_Hope.pdf. (Accessed on 25 January 2018.)

Mafeje, A. 1971. The Ideology of 'Tribalism'. Journal of Modern African Studies 9,2:253 - 261.

Malherbe, V.C. 1980. David Stuurman: Last Chief of the Hottentots. Journal of African Studies 39:47 - 65.

Mamdani, M. [1996] 2017. Citizen and Subject: Contemporary Africa and the Legacy of Late Colonialism. Johannesburg: Wits University Press.

Marks, S. 1972. Khoisan Resistance to the Dutch in the Seventeenth and Eighteenth Centuries. Journal of African History 13:1:55-88.

Masuzawa, T. 2005. The Invention of World Religions: Or, How European

Universalism was Preserved in the Language of Pluralism. Chicago: University of Chicago Press.

Mazrui, A.M. 1973: World Culture and the Black Experience. Seattle: 
University of Washington Press.

Mazrui, A.M. 1986: The Africans: A Triple Heritage. New York, and London: Little Brown and Co., and BBC.

Mazrui, A.M. \& W.M. Mutunga (eds.) 2004: Race, Gender, and Culture Conflict: Mazrui and His Critics. Trenton, New Jersey: Africa World Press. Mazrui, A.M. 2002a: Africanity Redefined, The Collected Essays of Ali A. Mazrui. Volume 1. Falola, T. (series ed.). Laremont, R.R. \& F. Kalouche. Trenton, NJ and Asmara, Eritrea: Africa World Press.

Mazrui, A.M. 2002b: Africa and other Civilizations: Conquest and CounterConquest: The Collected Essays of Ali A. Mazrui. Volume 2. Falola, T. (series ed.). Laremont, R.R. \& F. Kalouche. Trenton, NJ and Asmara, Eritrea: Africa World Press.

Mbembe, A. 2017. Critique of Black Reason. Dubois, L. (trans.) Durham \& London: Duke University Press.

Memmi, A. [1957] 1991. The Colonizer and the Colonised. Boston: Beacon. Moore, N.L. 1953. In a Class of their Own: The Bantu Education Act of 1953.

MHCS dissertation, University of Pretoria. Available at: https:// repository.up.ac.za/bitstream/handle/2263/53445/Moore_Class_2016. pdf? sequence $=1 \&$ isAllowed=y. (Accessed on 01 September 2017.)

Mphofu, W. 2017. Decoloniality as a Combative Ontology in African

Development. In Oloruntoba, S.O. and T. Falola (eds.): The Palgrave

Handbook on African Politics, Governance and Development. Palgrave Macmillan. Available at: https://link.springer.com/content/pdf/bfm\%3A 978-1-349-95232-8\%2F1.pdf. (Accessed on 10 January 2017.)

Muthu, S. 2003. Enlightenment against Empire. Princeton. Available at: https://www.amazon.com/Enlightenment-against-Empire-Sankar-

Muthu/ dp/0691115176. (Accessed on 18 August 2017.)

National Qualifications Framework or NQF Act of 2008 (Act No 67 of 2008.) 2008. Cf. SAQA 2008. Pretoria: Council on Higher Education. Available at: http:// www.saqa.org.za/docs/webcontent/ 2014/about.htm. (Accessed on 01 September 2017.)

Newton-King, S. 1981. The Rebellion of the Khoi in Graaf-Reinet: $1799-$ 1803. In Newton-King, S. \& V.C. Malherbe (eds.): The Khoikhoi Rebellion in the Eastern Cape, 1799 - 1803. Cape Town: Centre for African Studies, University of Cape Town. (Communications No. 5.)

Newton-King, S 1981. Background to the Khoikhoi Rebellion of 1799-1803. In Collected Seminar Papers on the Societies of Southern Africa in the 
$19^{\text {th }}$ and $20^{\text {th }}$ Centuries 10. London: University of London Institute of Commonwealth Studies. Available at: http://sas-space.sas.ac.uk/view/ collections/ics-ssa.html\#undefined. (Accessed on 24 September 2017.) Nyamnjoh, F.B. 2016. \#RhodesMustFall: Nibbling at Resilient Colonialism in South Africa. Cameroon: Langaa RPCIG.

Paquette, G. (ed.) 2009. Enlightened Reform in Southern Europe and its Atlantic Colonies c. 1750 - 1830. London: Ashgate.

Porter, R. \& M. Teich (eds.) 1981. The Enlightenment in National Context. Cambridge.

Prakash, G. 1995. After Colonialism: Imperial Histories and Postcolonial Displacements. Princeton. Available at: https://www.amazon.com/AfterColonialism-Histories-Postcolonial-Displacements/dp/0691037426. (Accessed on 18 August 2017.)

Quality Council for Higher Education 2008/ 2009. Pretoria: Council on Higher Education Available at: http://www.che.ac.za/media_and_ publications/annual-reports/annual-report-council-higher-education2008 2009. (Accessed on 01 September 2017.)

Resolutions of the Council of Policy of Cape of Good Hope. Cape Town Archives Repository, South Africa. Available at: https://www.google. co.za/search?ei=nfJcWpmWHuXUgAbBtq_QDg\&q=The+council+of+ policy+at+the+cape+MA\&oq=The+council+of+policy+at+the+cape+M A\&gs_l=psy-ab.3..33i22i29i30k1.28025.28672.0.29441.3.3.0.0.0.0. 307.565.2-1j1.2.0....0...1c.1.64.psy-ab..1.1.258....0.CbrjR2-c4h4. (Accessed on 26 January 2018.)

Rice, A. 2010/ 2018. Analysis: RIP Outcomes-based Education and don't Come Back. Daily Maverick 07 July. Available at: https://www.daily maverick.co.za/article/2010-07-07-analysis-rip-outcomes-basededucation-and-dont-come-back/. (Accessed on 15 Janaury 2018.)

Roodt, M. 2011. Research and Policy Brief: 'Model C' is the Model to Emulate. South African Institute of Race Relations. Available at: http:// irr.org. za/reports-and-publications/research-policy-brief/research-andpolicy-brief-model-c-is-the-model-to-emulate-1-february-2011.

(Accessed on 01 September 2017.)

Said, E. 1994. Culture \& Imperialism. London: Vintage Books.

Sales, J. 1975. Mission Stations and the Coloured Communities of the Eastern

Cape 1800 - 1852. Cape Town and Rotterdam: A.A. Balkema.

Saul, S 2008. Decolonization and Empire: Contesting the Rhetoric and Reality 
of Resubordination in Southern Africa and Beyond. Johannesburg: Wits University Press.

Scott, J.C. [1976] 1981. The Moral Economy of the Peasant: Rebellion and Resistance in Southeast Asia. New Haven \& London: YUP.

Scott, J.C. 1990. Domination and the Arts of Resistance: Hidden Transcripts. New Haven \& London: Yale University Press.

Shklar, J. 1969. Men and Citizens: A Study of Rousseau's Social Theory. Cambridge: Cambridge University Press.

Smit, J.A. \& J. van Wyk 1998/ 1999. Literary Studies in Post-Apartheid South Africa'. Culturelink (Croatia) Special issue: Cultural Change and Development in South Africa). Guest Editors: Abebe Zegeye and Robert Kriger. Also published in: Zegeye, A. \& R. Kriger (eds): Culture in the New South Africa after Apartheid. Volume 2. Cape Town: Kwela Books \& History OnLine.

Smit, J.A. 1999. Unlthinking White Mythologies. Alternation 61: 237 - 254. Available at: http://alternation.ukzn.ac.za/Files/docs/06.1/16\%20Smi. pdf. (Accessed on 14 October 2017.)

Smit, J.A. [2003]. Cultural Economy. Paper delivered at the NRF-funded Seminar on Culture and Identity, University of Durban-Westville, September 2003. Unpublished.

Smit, J.A. 2014. The Study of Religion at the University of KwaZulu-Natal, Durban, and Social Transformation. Alternation 21,2:309 - 343. Available at: http://alternation.ukzn.ac.za/Files/docs/21.2/14\%20Smi. pdf. (Accessed on 19 September 2017.)

Smit, J.A. 2016a. J.T. van der Kemp and his Critique of the Settler Farmers on the South African Colonial Frontier (1799-1811). Journal for the Study of Religion 29,1: 6-56. Available at: http://www.scielo.org.za/pdf/ jsr/v29n1/02.pdf. (Accessed on 21 September 2017.)

Smit, J.A. 2016b. J.T. van der Kemp's Link to the British Anti-slavery Network and his Civil Rights Activism on Behalf of the Khoi (1801 1803). Journal for the Study of Religion 29,2: 5-28. Available at: http://www.scielo.org.za/pdf/jsr/v29n2/02. pdf. (Accessed on 21 September 2017.)

Smit, J.A. [2017a]. Social Responsibility and Power I: J.T. van der Kemp's Interventions For and On Behalf of the Khoikhoi on the Eastern Cape Frontier (1801 - 1806). (Forthcominga.)

Smit, J.A. [2017b]. Social Responsibility and Power II: J.T. van der Kemp's 
Interventions For and On Behalf of the Khoikhoi on the Eastern Cape Frontier (1801 - 1806). (Forthcomingb.)

Smith, A. [1776] 1985. The Wealth of Nations. Harmondsworth, England:

Penguin.

South African Schools Act (Act No. 84 of 1996) 1996. Pretoria: Council on

Higher Education Available at: https://www.acts.co.za/south-african-

schools-act/index. html. (Accessed on 01 September 2017.)

Ukpong, J. 2004. Contextual Hermeneutics: Challenges and Possibilities. In

Mugambi, J.N.K. \& J.A. Smit (eds.): Text and Context in New Testament

Hermeneutics. Nairobi: Acton Publishers.

University of KwaZulu-Natal Strategic Plan 2017 2017. Available at: https://strategicplan 17-21.ukzn.ac.za/. (Accessed 07 November 2017.)

Van Onselen, C. 1982a. Studies in the Social and Economic History of the

Witwaterrand, 1886 - 1994: New Babylon. London \& New York:

HarperCollins.

Van Onselen, C. 1982b. Studies in the Social and Economic History of the

Witwaterrand, 1886 - 1994: New Nineveh. London \& New York: HarperCollins.

Van Onselen, C. 1996. The Seed is Mine: The Life of Kas Maine. A Share Cropper, 1894 - 1985. Canda: HarperCollins.

Van der Kemp, J. [1799] 1804. Transactions of the London Missionary Society: Volume I. London: London Missionary Society.

Wallerstein, I. [1991] 1995. Unthinking Social Science: The Limits of Nineteenth Century Paradigms. Cambridge: Polity Press.

Wallerstein, I. et al. 1996. Open the Social Sciences: Report of the Gulbenkian Commission on the Restructuring of the Social Sciences. Stanford: Stanford University Press.

West, G. 2016. The Stolen Bible: From Tool of Imperialism to African Icon. Leiden: Brill. (Biblical Interpretation Series.)

White Paper for Post-School Education and Training: Building an Expanded, Effective and Integrated Post-School System 2013. Pretoria: Department of Higher Education and Training Available at: http://www.dhet.gov.za/ SiteAssets/Latest\%20News/White\%20paper\%20for\%20post-school\%2 0education\%20and\%20training.pdf. (Accessed on 02 February 2018.) 
Johannes A. Smit

J.A. Smit

Religion \& Social Transformation University of KwaZulu-Natal smitj@ukzn.ac.za 